Historic, Archive Document

Do not assume content reflects current scientific knowledge, policies, or practices. 



\section{Special Fall Price List}

of

\section{BLUE RIBBON}

Farm, Field and Garden Seed
Hardy Plants, Shrubs, Bulbs, Etc.

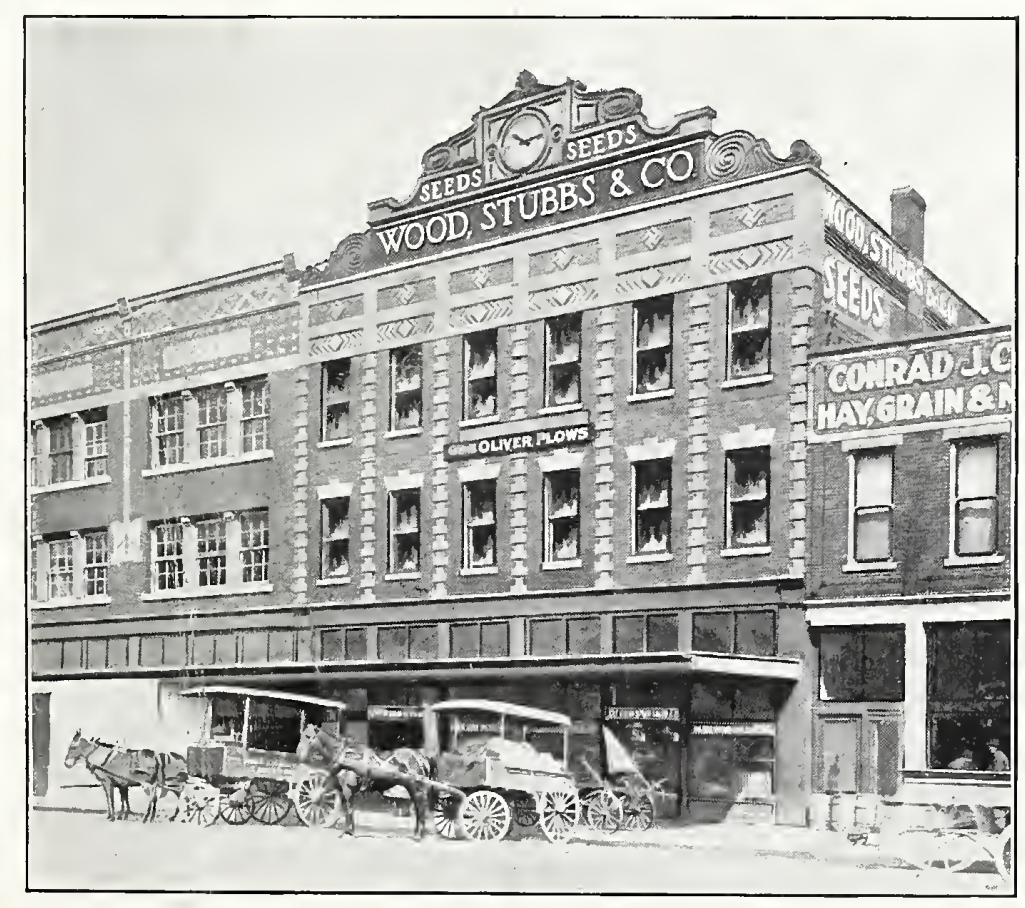

\section{August 1, 1916}

\section{WOOD, STUBBS \& CO. INCORPORATED SEEDSMEN}

219-221 E. Jefferson St.

LOUISVILLE, KY. 


\section{Suggestions to Customers}

\section{How to Send Money}

Remittance should be made either in the form of Express Money Orders, Post Office Order, Bank Draft or Registered Mail. We accept personal check without cost of exchange to our customers. One and two-cent postage stamps will be aceepted for sniall amounts provided they are carefully wrapped so as not to soil and stick together. Cash can be sent by registered mail and a receipt returned you by the post office. You run no risk in sending us money as we are well known and have been engaged in the seed business for many years. As to our financial responsibility you can ask any bank or trust company in Louisville or refer to the mercantile agencies.

\section{How to Order}

Be sure to write your name, post office and shipping point carefully on the order sheet furnished with this catalogue, and always give this information no matter how often you write us. Even if you send personal check with order, please do not neglect to write your name on the order as well as on the check, as they are separated immediately upon opening the envelopes. We would suggest early orders to insure their being filled complete, as there are invariably some stocks which are extremely scarce. We frequently have to disappoint some of our customers on orders sent late in the season.

\section{Note This Non-warranty}

Wood, Stubbs \& Co. give no warranty, expressed or implied, regarding description, quality, productiveness, or any other matter connected with the goods they send out, and will not be in any way responsible for the crop. If the purchaser does not accept the goods on these terms, they are to be returned at once, and any money that has been paid for them will be refunded.

\section{Express Rates}

There are special rates on seeds, plants and bulbs, and during the past year all rates have been very greatly reduced.

No Orders Sent C. O. D.

Unless one-third of amount is remitted in advance to cover charges.

\section{Prices}

All prices on seeds are made subject to market changes. There are always some crops in short supply and prices on these are bound to advance with the season, hence early orders are advisable.

\section{Purity and Germination}

As required by law, recently enacted, we will attach to each package of one pound or over, a tag giving an approximate percentage of purity and germination. These tests will be made by an expert in our office who has been schooled in the methods as used by the Kentucky Agricultural Experimental Station at Lexington, and the Seed Laboratory in Washington, D. C. We believe our methods of testing to be accurate and carefully made and in accordance with the latest methods and practices. We cannot guarantee a crop, however, and these tests are given for your guidance only and are not guaranteed. We are using every effort to grow and secure seed for use that will show the very highest tests for purity and germination.

\section{Seeds, Plants, Bulbs, Shrubs, Etc. (By Mail)}

Packets, ounces and one-fourth pounds, are mailed free at prices charged. Postage on bulk seeds to be paid by the purchaser. By a recent ruling of the Post Office Department we are now enabled to send packages of the above weighing eight ounces or less at one cent for two ounces or fraction thereof, regardless of distance. Shipments weighing over eight ounces will take pound rates according to zones.

\section{Errors}

We all make them, not intentionally, but they will creep in, especially during the busy season. We want you to be sure and write us at once if, on receipt of your order, you find anything wrong. Give us a chance to make matters right. We want every customer satisfied and are ready and willing to correct all errors.

\section{Market Gardeners}

And those using large quantities of seed should send us a list of their requirements. Prices will be furnished promptly and we can frequently make a substantial reduction on large orders.

\section{Cartage}

We do not charge for delivering goods to any depot or express office in this city.

\section{Our Spring Catalogue}

This will be issued in January and will cover very completely all the stock we carry, giving directions for growing, etc., mailed free on request. 


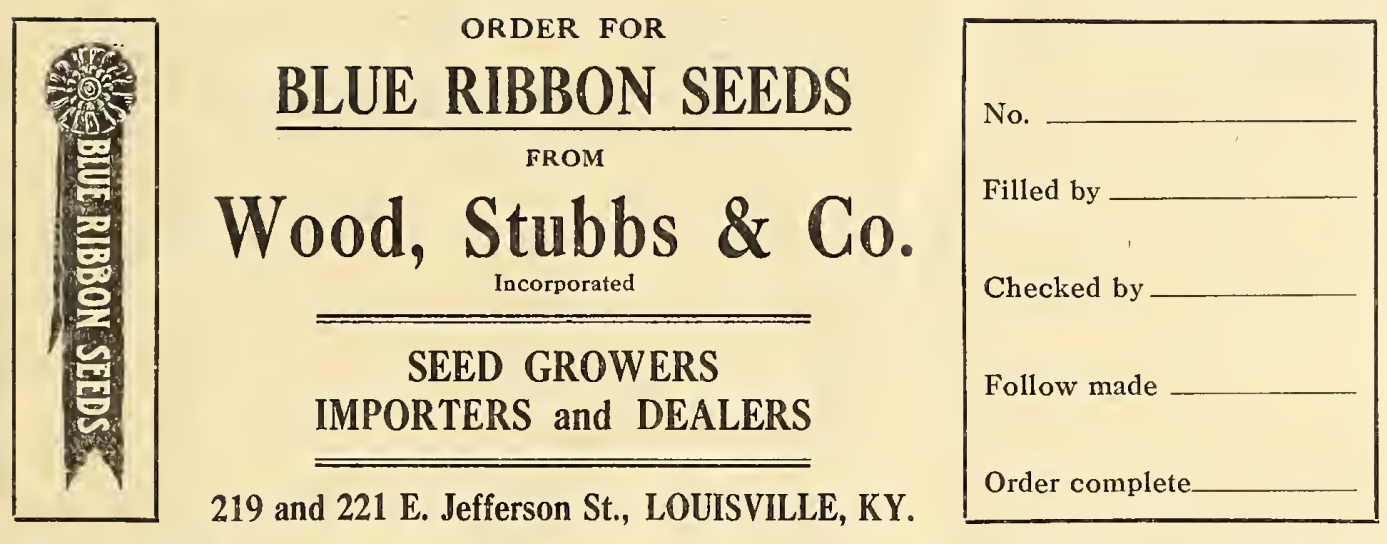

POSTAL RATES ON Seeds, Bulbs and Plants are now 1c for 2 oz, on packages weighing up to 8 oz., to any part of the country. ZONE RATES apply on packages weighing over 8 oz. Limit of weight to $1 \mathrm{st}$ and 2 nd zones is 50 lbs. to the package, 20 lbs. to all other zones.

NOOD STUBBS \& CO., Louisville, Ky.

Please enter my order and ship as follows, as per terms of your 1916 Catalogue:

Date

Tour Name

ost Office

Shipping Depot

County

end the Order by

(State here whether to send by Freight, Express or Mail, and route to ship by, if any special route is wanted) (If Ladies, state whether)
Miss or Mrs.

R. F. D.

Railroad

State

ARTICLES
AMOUNT ENCLOSED

M. 0 .

Check

Cash

Stamps

PRICE 


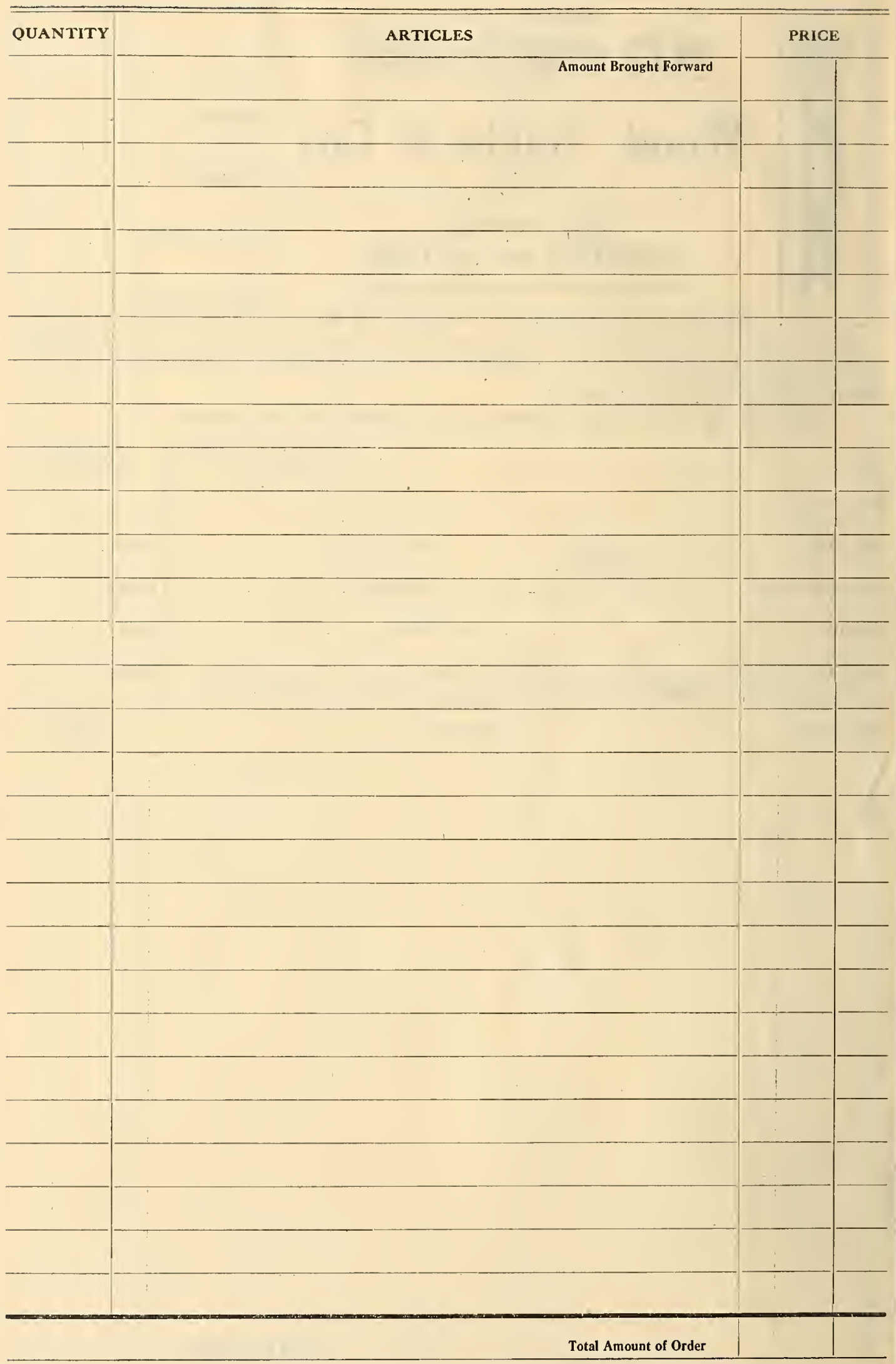




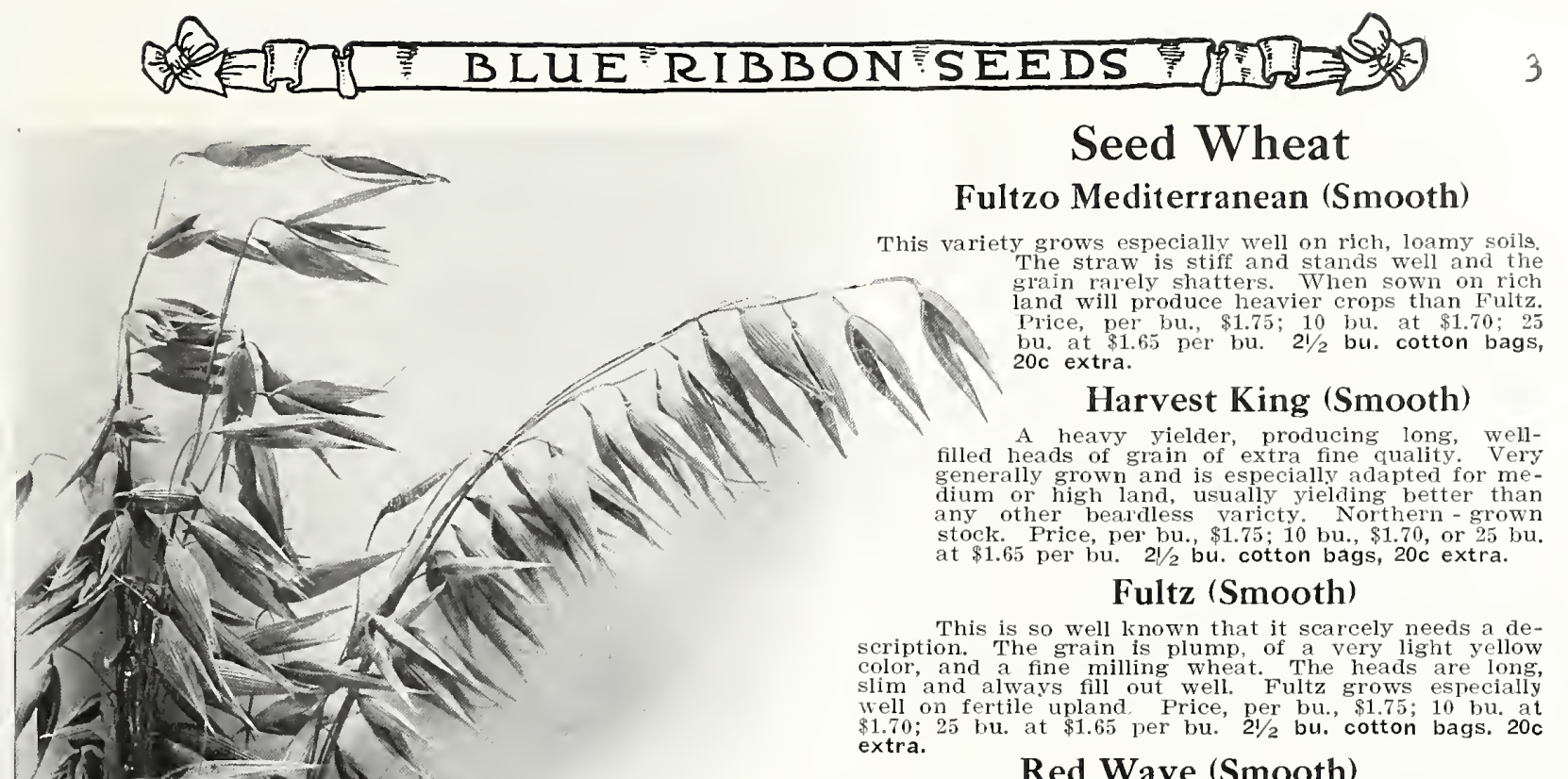

\section{Red Wave (Smooth)}

A splendid variety, having long broad heads well filled with large grain rather dark in color. Makes a very vigorous growth and the straw seldom Iodges. It has yielded heavily wherever grown. Price, per bu, $\$ 1.75 ; 10 \mathrm{bu}$ at $\$ 1.70 ; 25$ bu Wherever grown. Price, per bu., $\$ 1.75 ; 10$ bu. at
at $\$ 1.65$ per bu. $21 / 2$ bu. cotton bags, $20 \mathrm{c}$ extra.

\section{Poole (Smooth)} The grain is large, rather longer than Fultz, and possesses practically the same milling qualities. It seldom lodges, hence is of especial value on flat land and rich soils. Price, per bu., $\$ 1.75$; 10 bu, $\$ 1.70 ; 20$ extra.

\section{Fulcaster (Bearded)}

A bearded Wheat which is a reliable cropper, usually giving a very satisfactory yield of fine plump grain. The straw is very stiff and rarely rusts, making this a valuable variety for river bottoms and other places where rust is prevalent. Price, per bu., $\$ 1.75 ; 10$ prevalent. Price, per bu., $\$ 1.75$; 10 $21 / 2$ bu. cotton bags, $20 \mathrm{c}$ extra.

\section{Miracle (Bearded)}

This is reported to yield heavier in many places than any other variety of either bearded or smooth Wheats. The grain is large of good color and the straw is remarkably stiff, making it capable of holding the heavy heads of grain. It is vely hardy, seldom being winter-killed, and the plants stool much more fleely than other varieties. We recommend it highly for poor or upland soils. Price, per bu., $\$ 1.75 ; 10 \mathrm{bu}$. at $\$ 1.70 ; 25$ bu. at $\$ 1.65$. $21 / 2$ bu. cotton bags, $20 \mathrm{c}$ extra.

\section{Winter Turf Oats}

Winter Turf Oats are being sown more extensively each year in the South, having proved wonderfully satisfactory. When sown early it is hardy as wheat and will furnish splendid pasture during the Fall and Winter months, even up to March, when, if the stock is removed, it will continue growth and produce an excellent crop. The grain of Winter Turf is much larger than that of ordinary oats and the husk is thin, making it of high feeding value; the straw is also of high quality. Sow broadcast or in drills, one and one-half to two bushels per acre In this section August or early September is best; farther South and in Virginia, as late as October. Present prices, Blue Ribbon Recleaned, per bu., $80 \mathrm{c} ; 10$ bu., $78 \mathrm{c}$ : 25 bu. at $75 \mathrm{c}$ per bu. Bags included. Special quotations on large quantities.

\section{Fancy Northern Seed Rye}

Rye is very generally used throughout the country as a grain crop, for soiling, and both early and late pasturage. Being a vigorous grower, it will produce a crop on land too poor to grow other grains and a vigorous grower, it will produce a crop on plow under for green manuring thus buiding up the soil and putting it in condition to grow other crops. In this section it can be sown sol early as July and as late as December. We handle a very choice stock of Northern-grown seed, thoroughly recleaned. Sow one and one-quarter to two bushels per acre. Present prices, per bu., $\$ 1.35 ; 10$ bu. $\$ 1.30$. Bags $(21 / 2$ bu. $)$ each, $12 \mathrm{c}$ extra. Special prices on large lots.

\section{Winter Barley}

Choice Southern grown. This grain is not grown as widely as its merits deserve. It can be sown at the rate of one to one and one-half bushels per acre in September, October or November, and will give a much larger yield of grain than wheat. It stools freely and furnishes excellent Fall and Winter nasturage and can be cut for hay to advantage. It is a better crop excellent Fall and for either green

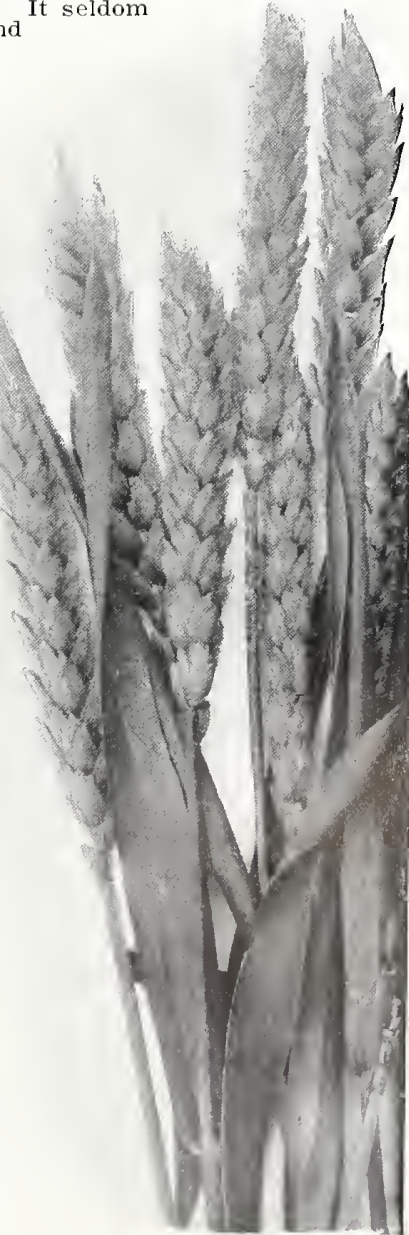

Red Wave Wheat 


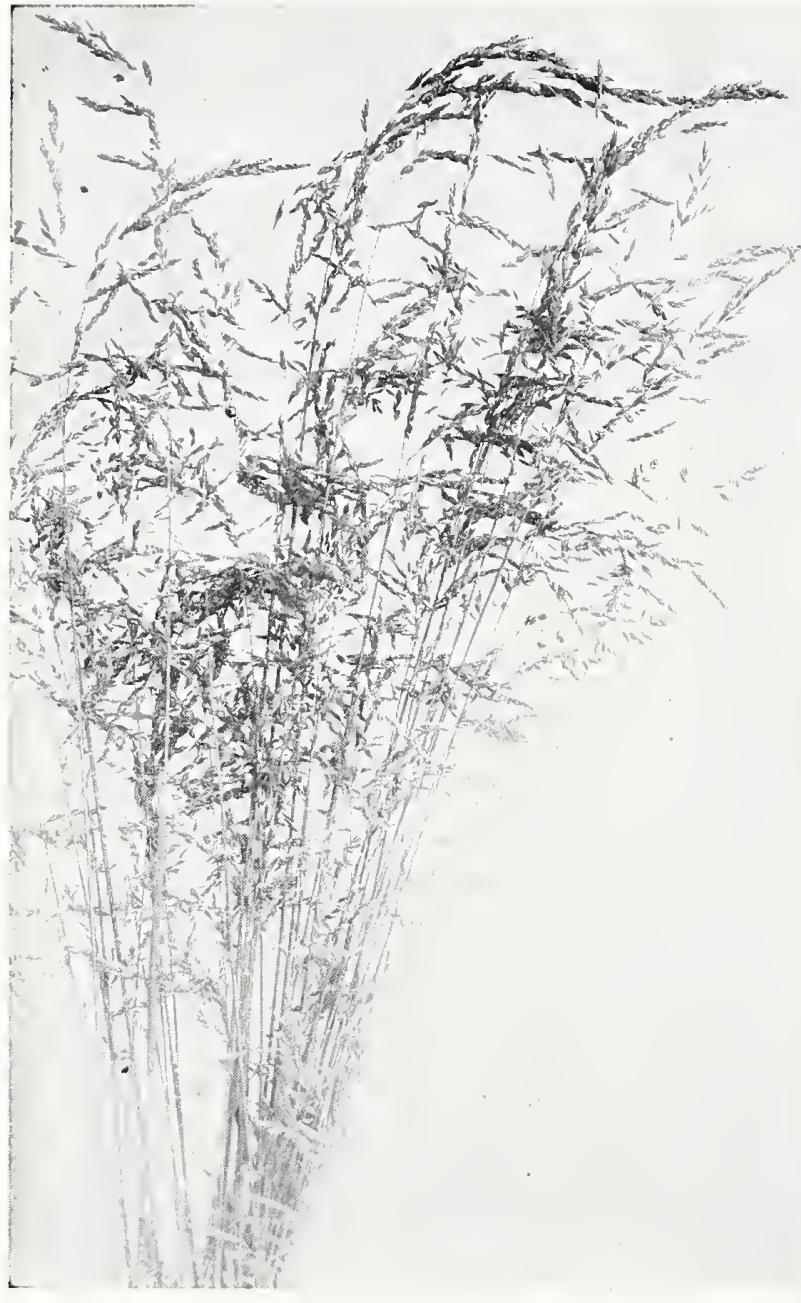

Kentucky Blue Grass

\section{Kentucky Blue Grass}

(Poa Pratensis) - Known throughout the country and very generally sown for pasture. Succeds on any fairly good land not too low, and is largely used for seeding lawns. Of acre and four to five bushels for lawn purposes. We are headquarters for fancy recleaned seed grown in the Blue Grass section of this state. Price, Blue Ribbon Brand, per lb., $20 \mathrm{c}$; per bu. (14 lb.), $\$ 2.00 ; 5$ bu. and over, $\$ 1.85$. Current prices on request.

\section{Red Top or Herds Grass}

(Agrostis Vulgaris) - A very desirable Grass for low, wet soils, valuable alike for hay and pasture and is also used in lawn mixtures. Always in demand for all purposes. When Sown alone, use eight pounds per acre. Price, Blue Ribbon 100 los., $\$ 13.00$. Ask for current prices. Bags, 20c extra.

\section{Tall Meadow Oat Grass}

(Avena Elatior) - Sometimes called Evergreen Grass or French Rye Grass, and introduced from Europe some years ago. It is a very desirable Grass for permanent pasture and meadows, not only because of its early growth in the Spring (ripening about the same time as Orchard Grass), but also from the frct that it produces a heavy growth after being mown, and lasts for several years. It grows well on the mown, and lasts for several years. It grows well on the same class of land that produces orchard Grass and does well When sown alone, as it covers the ground well, but is also Present prices, Blue Ribbon Brand, best grade, per lb., 20c; per bu. (11 lb.), $\$ 200 ; 5$ bu. and over, $\$ 1.90$ per bu. Write for prices in large quantities.

\section{Blue Ribbon Grass and Clover Seed for Fall Sowing}

WE URGE our customers to sow more grass and clover seed in the Fall rather than in the Spring. When sown early the grass makes sufficient growth so there is little chance of its freezing out in the Winter, whereas there is always a possibility of a dry summer and many acres are killed by the Summer drouth. Then again, if you seed in the Fall, you secure a crop of hay next year and excellent pasture which you would not otherwise obtain. It is always advisable to prepare the ground thoroughly and the top soil should be very fine. Sow the grass seed alone if possible. Better results will be obtained than if sown with grain. August, September and October are the best months to do seeding, but if this is done in the Spring-February, March and April. Sow plenty of seed and cover lightly.

Market Changes-Grain, grass and clover seed prices are constantly changing and following prices are those in effect at time this catalogue was printed (August 1st). If desired, we shall be glad to make special quotations at any time.

\section{Orchard Grass}

(Dactylis Glomerata)-This is one of the very best Grasse for upland, loamy or moderately stiff soils, affording a large amount of pasturage as well as making excellent hay if cut when in bloom. It grows about three feet high and matures much earlier than Timothy, does not exhaust the soil and will produce two to three tons per acre of fine hay. Having a tendency to grow in clumps, it does better if sown thickly. a the bushels being the amount usually one and one-es especially well if used with other grasses in sown. It does especiagested in our Mixture No. 2, as given mixture, such as suggested in our Mixture No. 2, as given on page 5. We regret to have to report a very shout any again this year, and prices are subject to change at any time. Present prices, Blue Ribbon Brand, fancy recleaned
seed, per lb., 25c; per bu. (14 lb. $), \$ 2.75 ; 5$ bu. and over, $\$ 2.65$.

\section{Timothy}

(Phleum Pratense)-No Grass is better known than this, nor more generally grown, as it produces the best hay of al Grasses, but is of little value for pasture. It produces good hay on almost any class of land, but in this section is bes suited to bottom lands or good, rich, well-drained soil. It yields about one and one-half to two tons of hay per acre, which is always in demand. Frequently used to seed down with wheat or rye in the Fall. If used alone, sow one peck per acre. Our Blue Ribbon Brand is fancy, heavy seed of high germination. Present price, Blue Ribbon Brand, per lb., $10 \mathrm{c}$; per bu. ( $45 \mathrm{lb}$.), $\$ 3.65 ; 5$ bu. lots, $\$ 3$.

\section{Italian Rye Grass}

(Lolium Italicum) - A valuable grass for moist soils, mak(Lith used either alone or in mixture with other Grasses for hay. If sown alone, use two to three bushels per acre if with Red Clover, one-half to one bushel per acre. Per ib., 15c; per bu. (14 lb.), $\$ 1.25 ; 5$ bu. and over, $\$ 1.20$ per bu. Bags included.

\section{Perennial Rye Grass}

(Lolium Perenne) - Used very largely in Europe for both hay and pasture, and well adapted to this section also for both. It is a strong grower, starting early in the Spring, and can be used to great advantage in mixtures. When sown alone, use two to three bushels per acre, or eight to ten
pounds in mixture. Per lb., $15 \mathrm{c}$; per bu. (14 lbs.), $\$ 1.25 ; 5 \mathrm{bu}$. and over, $\$ 1.20$ per bu. Bags included.

\section{English Blue Grass}

(Meadow Fescue or Randall Grass) (Festuca Pratensis)-A splendid Grass for permanent pastures, starting early and also furnishing excellent pasture very late in the season, being very nutritious; stock thrives well on it. While its greatest value is as a pasture Grass, it also makes good hay, growing on almost any soil, thriving best in that which is moist. Should be used in mixtures with other grasses, almoist. Should be used in mixtures with other grasses, although if sown for hay can be used alone at the rate of one Ribbon Brand, 20c; per bu. (24 lbs.), $\$ 2.50$. Bags included. Current prices on request. 


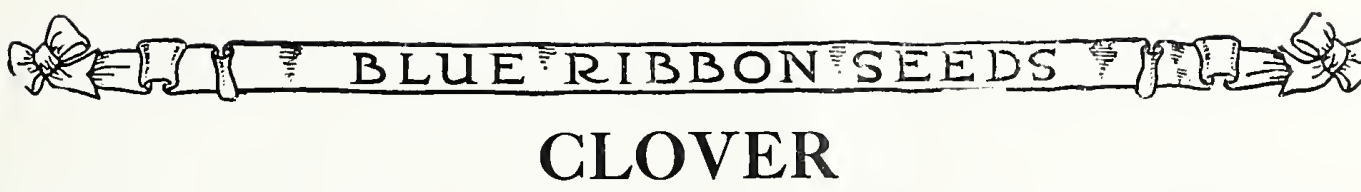

$\mathbf{N}^{\circ}$ FARMER can grow a maximum crop unless he uses Clover. It puts the ground in better condition than any other crop and it pays as a hay crop or pasture, to say nothing of the improvement in the soil after growing it.

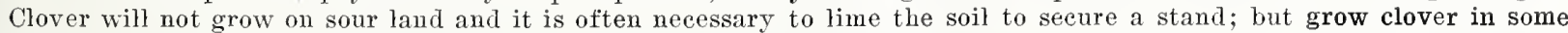

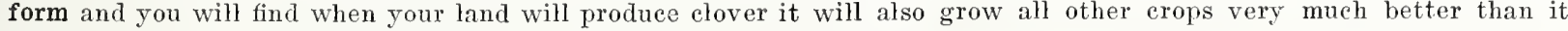
now does.

Prices subject to market changes. All orders will be filled at market price on day order is received. Our Blue Ribbon brands are the finest the market affords, both as to purity and germination. Our equipment for recleaning all kinds of grass seed is the best procurable, and we reclean all seed sold.

\section{Crimson Clover (New Crop)}

Crimson Clover can be sown 12 to 15 pounds per acre in June, July, August and September, August usually being best. It is better to have a firm seed-bed, and if recently broken, harrow until ground becomes finely pulverized, then board or roll, so as to get a hard, firm seed bed. It is preferable to wait for a rain on the prepared land, and then after it is dry enough, break the crust with a sharp spike tooth harrow and then sow the seed. Loamy land plowed or cultivated a month or two then sow the seed. Loamy land plowed or cultivated a month or two and rolled. In other words, it is important that seed be covered lightly and rolled. In other words, it is important that seed be covered lightly
and firmly. Blue Ribbon Brand, per lb., $15 \mathrm{c} ; \$ 8.75$ per bu.; 5 bu. Iots at $\$ 8.65$ per bu. Market very firm and seed scarce. Order early. Bags, each, $20 \mathrm{c}$ extro.

\section{Red Clover}

(Trifolium Pratense) - The most important of all Clovers and known everywnere. Usually sown in the Spring, but we find Fall seeding very satisfactory, especially if seeded alone or with other Grasses. Use one-eighth to one-quarter bushel per acre alone, and five to six pounds if used with other Grasses, and be careful where you buy seed, for there are many grades offered, containing weed seed hard to clean out Prices govern quality, and ovir Blue Ribbon Brand is offered as out. Prices govern quality, and otir Blue Ribbon Brand is offered as low as it is possible to sell fancy seed. Price, $20 \mathrm{c}$ per $1 \mathrm{~b} ; \$ 10.00$ per bu.
of 60 lbs.; 5 bu. lots and over, $\$ 9.85$ per bu. Bags holding $2 \frac{1}{2}$ bu., $20 \mathrm{c}$ each extra. Prices fluctuate; current prices on request.

\section{Sapling or Mammoth Clover}

Known also as Pea Vine and English Clover. Use the same amount of seed per acre as for Red. Blue Ribbon Brand, per Ib., 20c; per bu. $\$ 11.00$. Bags, 20c extra. Current prices on request.

\section{Alsike or Swedish Clover}

(Trifolium Hybridum) - Is hardier than other clovers, hence more lasting, and will grow better on damp ground. When used alone, sow five to eight pounds per acre; in mixtures, three to four pounds. Price, Blue Ribbon Brand, per lb., 20c; per bu. (60 Ib.), $\$ 10.25 ; 5$ bu. and over, $\$ 10.00$ per bu. Bags $20 \mathrm{c}$ each extra. Current prices on request.

\section{White Clover}

(Trifolium Repens)-An excellent addition to permanent pasture mixtures and always used in lawn mixtures, as it forms a close sod and does not wash in heavy rains. Sow one to two pounds per acre in mixture. Price, per $1 \mathrm{~b} ., 50 \mathrm{c} ; 5 \mathrm{lb}$. and over, $45 \mathrm{c}$ per lb.,Bags $20 \mathrm{c}$ each extra.

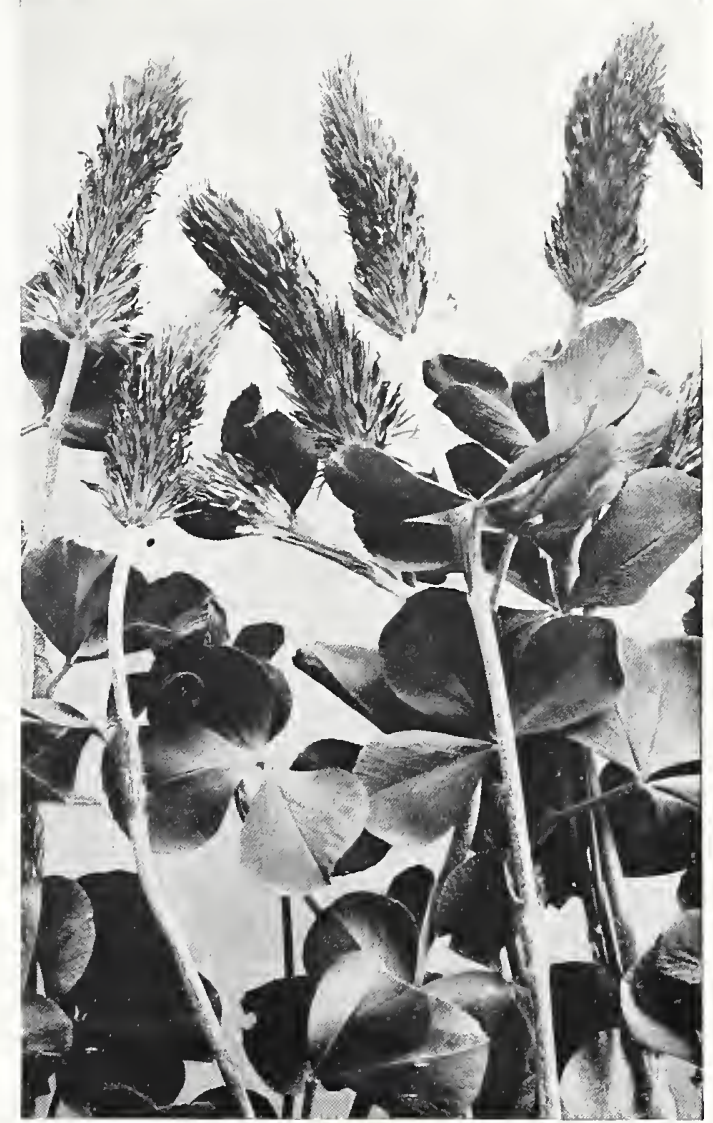

Crimson Clover

\section{Grass Seed Mixtures for Hay and Permanent Pastures}

\section{Mixture No. 1}

For light sandy or loamy soils. Perennial Rye Grass, Orchard Grass, Fancy Red Top, Alsike Clover, Tall Oat Grass, Kentucky Blue Grass, Sheep Fescue, Red Clover, Sow 20 pounds per acre. Price, per lb, 25c; 20 lb., $\$ 3.50 ; 100 \mathrm{lb}$. $\$ 15.50$.

\section{Mixture No. 2}

For limestone, stiff, or loamy upland soils. Orchard Grass, Kentucky Blue Grass, Perennial Rye Grass, Tall Oat Grass, Fancy Red Top, Red Clover. Sow 25 pounds per acre. Price, per lb., 20c; 25 lb., $\$ 4.00 ; 100$ lb., $\$ 15.00$.

\section{Mixture No. 3}

For heavy loam or clay, or bottom lands. Timothy, Fancy Red Top, Meadow Fescue, Alsike Clover, Mammoth Clover. Sow 18 pounds per acre. Price, per 1b., 20c; 18 1b., \$2.75; 100 lbs., $\$ 13.00$
Mixture No. 4

For wet bottom land, subject to overflow. English Blue Fancy Red Top, Italian Rye Grass, Rough Stalked Meadow Mammoth Clover. Sow 25 pounds per acre. Price, per lb., $20 \mathrm{c} ; 25$ lb., $\$ 3.85 ; 100$ lb., $\$ 15.00$.

\section{Mixture No. 5}

Especially for the South on any good soil, withstanding hot, dry weather. Bermuda Grass, Fancy Red Top, English Blue Tall Oat Grass. Sow 15 pounds per acre. Price, per lb. $30 \mathrm{c} ; 15$ lb. $\$ 3.25 ; 100$ lb., $\$ 20.00$

\section{Wood, Stubbs \& Co.'s Special Pasture Mixture}

This is a special mixture for affording a quick growing and asting tasting pasture for stock and poulds where sod of somewhat rough turf is desired It is suitable either for high or low 等 Autumn, but cannot be cut for hay. Sow 16 pounds per acre. Price, 16 lb., $\$ 2.50 ; 100$ lb., $\$ 12.00$. Bags included. 


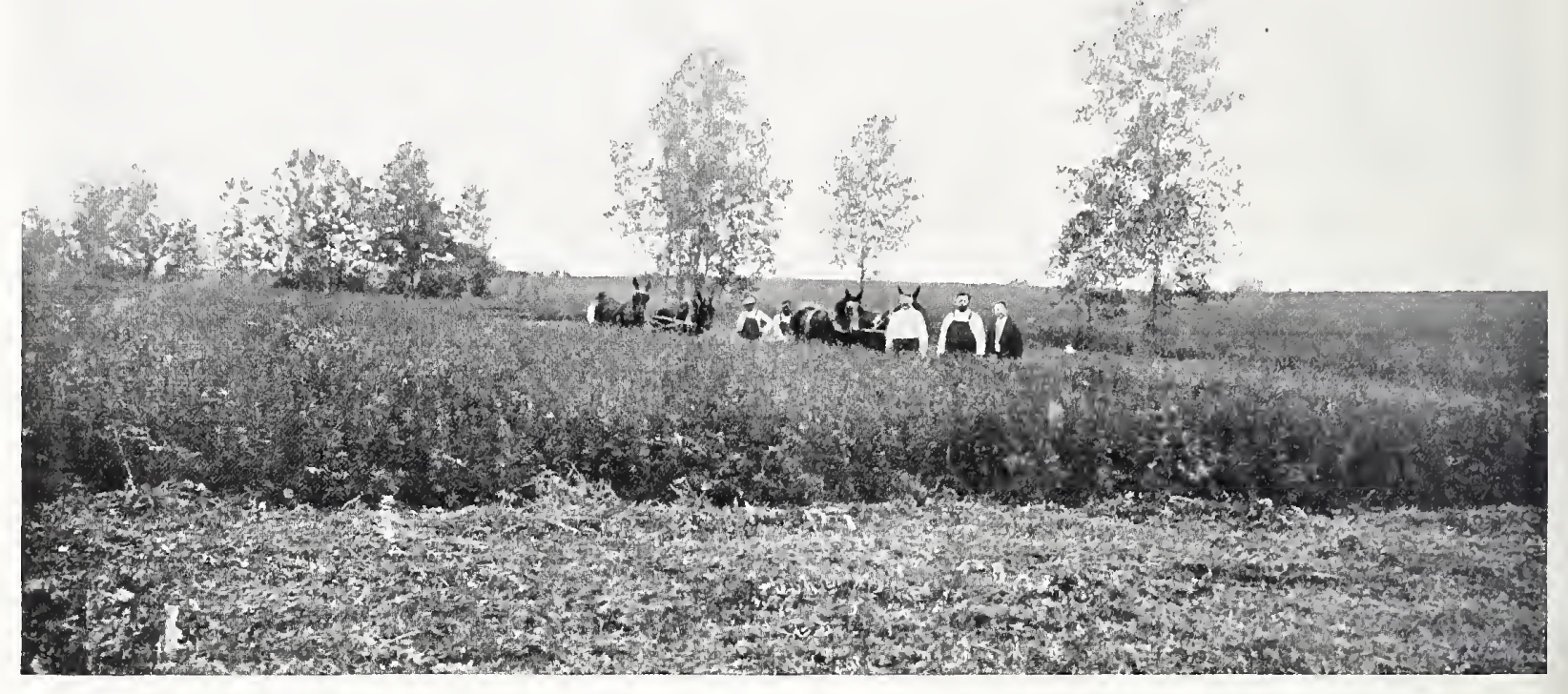

A Second Cutting of Alfalfa. (Courtesy C. C. Clay Alfalfa Land Co., Demopolis, Ala.)

\section{Alfalfa or Lucerne}

The hardiest and most lasting of all Clovers and when once established the most productive as well as the best soil enricher of all. It can be cut for hay several times a year, yielding bountifully at each cutting and the hay is of the highest feeding value.

The question of securing a good stand of Alfalfa is largely settled by thorough preparation of the soil, not attempting to start it on poor soil and not seeding on wet land. It does best on a loamy limestone soil, the lime being very essential to its growth; and where lime is absent from the soil, it should be added, and as the roots penetrate to a great depth. it is not advisable to sow it on very heavy clay soils.

Thi ground cannot be too well prepared. Plow deeply, harrow thrroughly, making the top soil fine as possible, then roll to make it firm. Use 20 pounds of seed to the acre, sowing broa!cast. Harrow lightly to cover the seed, then roll again. If prissible, apply about 200 pounds of some good fertilizer. Generally speaking, inoculation is not necessary, but if desired we can furnish inoculating material and will gladly furnish full particulars regarding its use.

Spring seeding is done largely. The seed is also sown in August in this vicinity; farther South, in September and October. Be careful about the seed you buy. Old Alfalfa seed is worthless. There is also a lot of adulterated seed offered. You can depend on our Blue Ribbon Brand. American grown. Price, per lb., 30c; 10 lb., $\$ 2.60$; bu., $\$ 13.25 ; 5$ bu. lots, $\$ 13.00$ per bu. Bags $20 \mathrm{c}$ each extra.

Inoculation Bacteria for Alfalfa - Trial size, 50c; for one acre, $\$ 2.00$; five acres, $\$ 6.00$.

\section{Dwarf Essex Rape}

Rape is a plant resembling a "Swede" turnip or Ruta Baga in color and form of foliage, but it does not make a large root. It fumishes and immense amount of feed and can be grown on any soil, being particularly adapted to the South. The Alabama Experiment Station, stating after careful trials c" "Quality of product good for both hogs and cattle. The carry more hogs through our hot, dry summers than four times the amount of land planted in anything else ever grown here.

We do not know of a crop which costs so little to produce and which will yield such big returns quickly. You can fatten all your sheep and hogs with yery little grain if you pasture them on Rape. Try it this year and be convinced. pasture them on Rape. Try it this year and be convinced. pounds per acre. If sown in corn at last working, three to four pounds is sufficient. Price, per lb., 15c; $101 \mathrm{~b}$., $85 \mathrm{c} ; 100$ lb., $\$ 7.00$. Bags holding 100 lb., $20 \mathrm{c}$ each extra.

\section{Bokhara or Sweet Clover}

Melilotus Alba, Biennial (Bokhara or White Sweet Clover). Melilotus Officinalis, Biennial (Yellow Sweet Clover). The first mentioned, Melilotus Alba, is the strongest grower and the best. When young it resembles Alfalfa to such a degree that it is often mistaken for it, but when mature, which is during its second season, it attains a height of five to six feet and blooms from June to October. The roots of all varieties are large. fleshy and much branched and go down to considerare large, fleshy and much branched and go down to considerond year, if the plant ripens seed. If cut before seed is ripe or of pastured so that seed is not matured, the plant lasts over several seasons.

The seed can be sown broadcast in wheat in mid-Winter or seeded same as Red Clover in the Spring. It may also be seeded in late Summer in a similar way to Alfalfa, 20 to 30 pounds to the acre being required.

Sweet Clover is being used most extensively here in Kentucky as a pasture, as once stock becomes used to it, it is eaten as readily as Red Clover and the stock appear to thrive on it equally as well. It is especially good as an early pasture. For hay it is eut just as it is coming into bloom and is ble plant for bees, being the principal honey plant in some sections.

It will grow on soils too poor to produce either Clover or Alfalfa, and eventually brings them to a high state of fertility, inoculating the soil and putting it in excellent condition to grow Alfalfa. We can furnish two varieties at the following prices:

Unhulled Mammoth White-Per 1b., 20c; 25 lb., 15c per lb. $100 \mathrm{lb}$. and over, $13 \mathrm{c}$ per $1 \mathrm{~b}$.

Hulled Mammoth White-Per lb., 25e; 25 lb., 23c per lb.; $100 \mathrm{lb}$. and over, $20 \mathrm{c}$ per $\mathrm{lb}$.

Unhulled Mammoth Yellow-Per 1b., 20c; 25 lb, $15 \mathrm{c}$ per lb; $100 \mathrm{lb}$. and over, 13c per lb.

Hulled Mammoth Yellow-Per lb., 25e; 25 1b., 18c per lb.; 100 lb., $\$ 17.00$.

\section{Hairy Vetch}

Hairy Vetch is unexcelled as a pasture plant. It is relished by all kinds of stock and is fully equal to olover or alfalfa in feeding value. Sown in the Fall, it affords grand pasturage throughout the Winter and Spring. It can be pastured on into March, then if the stock is removed it will come on rapidiy and yield a heavy crop of hay. As a cover crop in cotton. tobacco or late corn, it is of great value, as it can be seeded after the last cultivation and turned under in the Spring, after the last cultivation and turned under in the Spring, affording a large amount of humus and quickly building up the soil. Seeding can be done from July to September in this latitude; farther south it can be sown late as November. Use 40 to 50 pounds per acre, either broadcast or drilled.
Per $1 \mathrm{~b} .20 \mathrm{c} ; 10 \mathrm{lb}$. and over, $19 \mathrm{c} ; 100 \mathrm{lb}$ and over, $1 \mathrm{c}$ per $1 \mathrm{~b}$. Bags extra, 20c each. 


\section{Abridged List of Vegetable Seeds for Fall Planting}

TE GIVE below an abridged list of vegetable seeds for Fall anl early Spring planting. Our stoeks are the finest obtainable, and market growers are sure of uniform growth if they use Blue Ribbon strains.

POSTAGE ON SEEDS Packets, ounces, one-quarter pounds and one-half pounds are mailed free at prices quoted. For larger mailed free. Add $5 \mathrm{c}$ per pint and $10 \mathrm{c}$ per quart for Beans, when vanted by mail.

\section{Beans}

We are headquarters for seed Beans, handling them in immense quantities. This year our trade more than doubled. No order toolarge for us. Let us hear from you.

\section{GREEN POD VARIETIES Longfellow}

A medium early variety, with pods $5 \frac{1}{2}$ to $6 \frac{1}{2}$ inches long, green and of good quality Considered by many a very profitable variety for market. Pkt., 10c; pt., $20 \mathrm{c}$; qt., 35c; gal., $\$ 1.00$; bu., $\$ 7.00$.

\section{Improved Red Valentine}

(Blue Ribbon Strain)-A very superior stock of this standard variety. Early and productive. Pkt., 5c; pt., 20c; qt., 35c; 4 qts., $\$ 1.00 ;$ bu., $\$ 7.00$.

\section{Giant Stringless Green Pod}

Resembles Valentine, a little later, but pods are a third larger. Very satisfactory. Pkt., 10c; pt., 20c; qt., 40c; 4 qts., $\$ 1.50$; bu., $\$ 10.00$.

Black Valentine-Pkt., 10c; pt., 15c; qt., 30c; gal., 90c; bu., $\$ 6.00$.

Early Yellow Six Weeks-Pkt., $10 \mathrm{c} ;$ pt., $15 \mathrm{c}$; qt., $30 \mathrm{c}$; gal., $\$ 1.00 ;$ bu., $\$ 6.00$.

1000 to 1 , or Refugee-Plkt., 10c; pt., 15c; qt., 30c; gal., $\$ 1.00 ;$ bu., $\$ 7.00$.

\section{WAX POD VARIETIES}

Our stocks are very low and we would prefer making special quotations on these New crops will be ready to deliver in December. Our prices will be right, so be sure and call on us for your supply of Wax Beans.

\section{Keeney's Rustless Golden Wax}

A very heavy yielder, almost free from rust. Inclined to send up tendrils similar to a pole bean. The pods are flat, of a bright yellow color and entirely stringless. A fine Bean. Good for market or the home garden. Pkt., 10c; pt., 20c; qt., 35c 4 qts., $\$ 1.00$; bu., $\$ 8.00$.

\section{Dwarf German or Black Wax}

A round-podded Wax Bean of good quality and fine appearance. Well known everywhere. Plkt., 10c; pt., $25 \mathrm{c}$; qt., $40 \mathrm{c} ; 4$ qts., $\$ 1.25$.

\section{Dwarf Golden Wax}

A well known variety, very early and a fine, bright yellow color; pods are flat and of good size. Plkt., $10 \mathrm{c} ;$ pt. $20 \mathrm{c} ;$ qt., $40 \mathrm{c} ; 4$ qts., $\$ 1.25$; bu., $\$ 8.00$.

\section{Currie's Rustproof Wax}

modcrate grower, yery early and productive, producing rather flat pods about 51/2 inches long. Pkt., 10c; pt., 20c; qt., 40c; 4 qts., $\$ 1.25 ;$ bu., $\$ 8.00$.

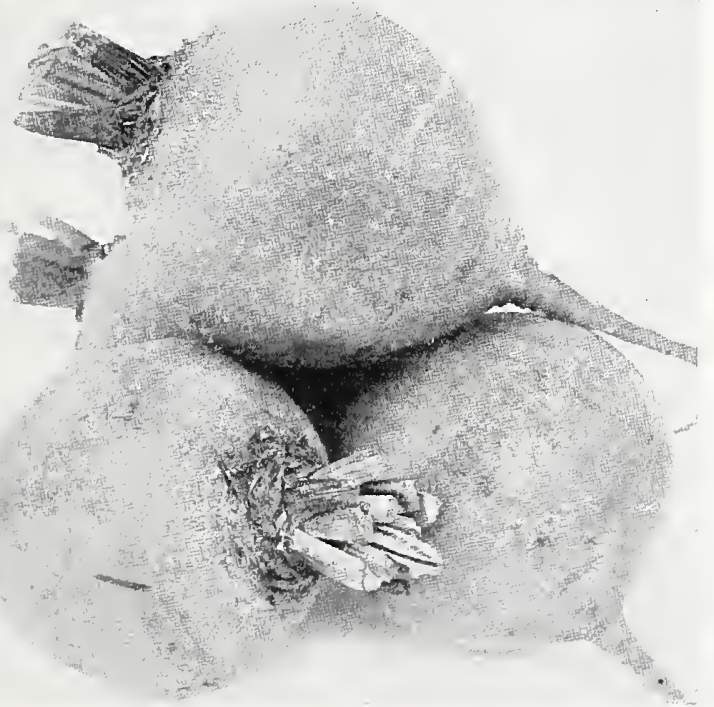

This is one of our specialties and we have a strain which produces is one of our specialties and we have a strain which proshape, growing to a good marketable size very rapidly Try our Crosby if you want a satisfactory crop. Pkt., 5c; oz., 10c; $1 / 1 \mathrm{lb}$. $35 \mathrm{c} ; 1 \mathrm{~b} ., \$ 1.00 ; 5 \mathrm{lb}$. and over, $90 \mathrm{c}$ per $1 \mathrm{~b}$.

\section{Detroit Dark Red}

A highly colored Turnip Beet, very popular with many growers on account of its fine appearance, both as to color and shape. The tops are small, which permits of its being grown quite thick. Pkt. 5c; oz. 10c; $1 \frac{1}{1 b}, 35 \mathrm{c} ; 1 \mathrm{~b} ., \$ 1.00 ; 5 \mathrm{lb}$, and over, $90 \mathrm{c}$ per $1 \mathrm{~b}$

\section{Extra Early Exclipse}

(Blue Ribbon Stock)-Very early, globe shape and of fine dark color: a popular variety, of which we have a gilt edge strain. Pkt. 5c; oz., 10c; 1/4 lb., 35c; 1b., $\$ 1.00 ; 5 \mathrm{lb}$. and over, 90c per $1 \mathrm{~b}$ The following four standard varieties at uniform price of 'The following four standard varieties at uniform. Bastian's Early Blood Turnip, Extra Early Egyptian. Edmonds Early Blood Turnip, Improved Early Blood Turnip. Half Long Blood Red ( Pkt,, 5c; oz., 10c; $1 / 4$ lb., 20c; 1b., 75c Long Smooth Blood Red Sk, $^{5}$ ib. at $70 \mathrm{c}$ per lb. 


\section{Cabbages}

\section{Charleston Wakefield (Blue Ribbon Strain)}

A variety which is used very largely by Southern growers and one which does well on all soils. It forms a solid, pointed head, and practically every plant heads up well. We have a splendid strain of this plant heads up well. We have a splendid strain

\section{Henderson's Early Summer}

This comes along right after the Wakefield and is a fine Cabbage. It forms a solid, round head, rather flat, of good size and fine quality.
$1 / 4$ lb., $60 \mathrm{c}$; lb., $\$ 2.00$.

Select Early Jersey Wakefield-Best extra early. Plkt., 5c: 20c; $1 / 1$ lb., 60c; lb., $\$ 2.00$.

Copenhagen Market-Extra early, flat head, very fine. Pkt., 10c; oz., 30c; $1 / 4$ lb., $\$ 1.00 ; 1 b ., \$ 3.00$.

Early Flat Dutch-Good main crop variety. Pkt., 5c; oz. $15 \mathrm{c} ; 1 / 4$ lb., $50 \mathrm{c} ; 1 \mathrm{~b} ., \$ 1.50$.

All-Head Early-Standard second early variety. Plkt., 5c: oz., $15 \mathrm{c} ; 1 / 4$ lb., $50 \mathrm{c} ; 1 \mathrm{~b} ., \$ 1.50$.

Solid South-A popular second early flat head. Flkt., 5c; oz., 20c; 1/4 lb., 60c; 1b., $\$ 2.00$.

Henderson's Succession - An all-seasons' variety. Pkt. $5 \mathrm{c} ;$ oz., 20c; $1 / 4$ lb., $60 \mathrm{c} ; 1 \mathrm{~b},, \$ 2.00$.

Louisville Drumhead-(Home grown)-Plit, 10c; oz, 25c; $1 / 4$ lb., $85 \mathrm{c} ; 1 \mathrm{~b}$., $\$ 3.00$.

Louisville Drumhead - Northern grown) - Pkt., $5 c ;$ oz. 20c. 1 1b., 60c: 1b., $\$ 2.00$

\section{Cauliflower}

\section{Blue Ribbon Snowball}

Growel's are verv narticular about their seed of this vegetable, and when they secure a good strain they stick to it. We are getting more customers every year for this Blue Ribbon stock Gardeners have tested it out alongside of other seed and are never disappointed with it. Grown in Denmark by the most experienced seedmen. We purchase it direct. Pkt., $20 \mathrm{c} ; 1 / 4$ oz., $85 \mathrm{c} ;$ oz., $\$ 3.00 ; 1 / 4$ lb., $\$ 10.00 ; 1 \mathrm{~b} ., \$ 36.00$.

\section{Danish Giant or Dry Weather Cauliflower}

A large variety which appears to have the ability to develop a head even under adverse conditions. The leaf growth is large, protecting the head from the sun. Later than Snowball. Pkt., 20e; 1/ oz, 85c; oz. $\$ 3.00 ; 1 / 4 \mathrm{lb}, \$ 10.00 ; 1 \mathrm{~b}, \$ 36.00$.

Early Snowball-A standard stock. grown everywhere. Our seed is extra fine. Pkt., $10 \mathrm{c} ; 1 / 4$ oz., $60 \mathrm{c} ; \mathrm{oz} ., \$ 2.00 ; 1 / 4 \mathrm{lb} ., \$ 7.00$.

Extra Early Dwarf Erfurt-Used largely by market growers and a good variety. Plkt., $10 \mathrm{c} ; 1 / 1 \mathrm{oz}, 60 \mathrm{c} ; \mathrm{oz} ., \quad \$ 2.00 ; 1 / 4 \mathrm{lb}$., $\$ 7.00$.

\section{Collards}

North Carolina Short Stem-Its flavor and cooking qualities are the very best, and it has unquestionably proved far superior to any Collards in cultivation. Pkt., 5c; oz., 10c; 1/ 1b. perior to any

True Georgia-The old standard sort for use in the South Pkt., 5e; oz., 10e; 1/4 lb., 20c; 1b., $50 \mathrm{c}$.

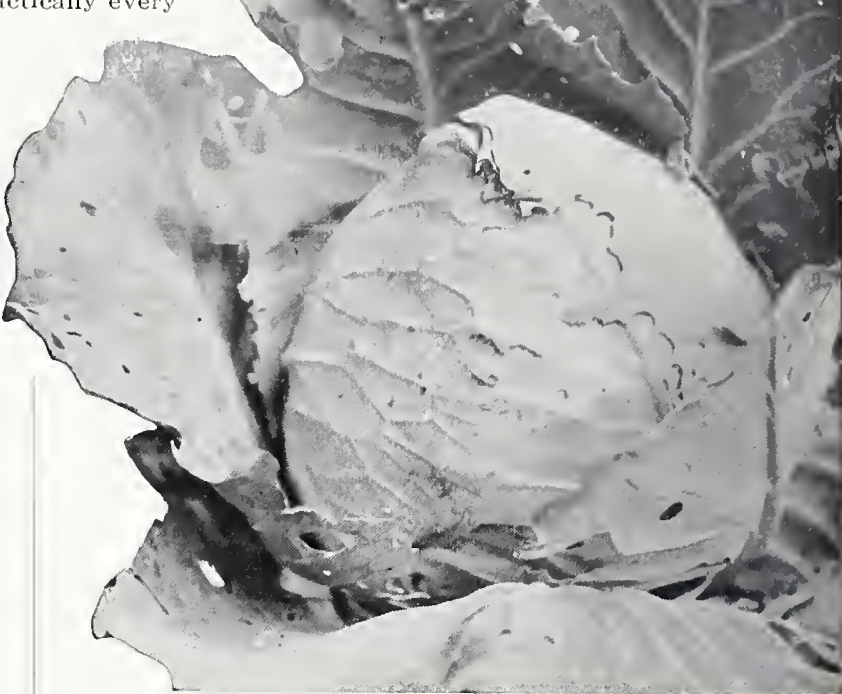

\section{Carrots}

\section{Chantenay}

One of the most popular varieties grown. Medium early, of good size and a heavy cropper. Pkt., $5 \mathrm{c} ; 0 \mathrm{z} ., 10 \mathrm{c} ; 1 / 4 \mathrm{lb}$., $35 \mathrm{c}$;

\section{Danvers Half-Long}

A splendid Carrot, largelv grown for market. Crop always uniform and of good quality. Pkt., $5 \mathrm{c}$; Oz., $10 \mathrm{c} ; 1 / 41 \mathrm{~b} ., 35 \mathrm{c}$; 1b. $\$ 1.00$

\section{Improved Long Orange}

Very generally grown for a main crop. A splendid keeper and useful for either table, market or stock feeding. Pkt., $5 \mathrm{c}$ oz., 10c; $1 / 4$ lb., 35c; lb., $\$ 1.00$.

Scarlet Intermediate-Pkt., 5c; oz., $10 \mathrm{c} ; 1 / 4$ lb., 35c; lb., $\$ 1.00$. Early Scarlet Horn-Pkt., 5c; oz., 10c; 1/4 1b., 35c; lb., $\$ 1.00$.

Oxheart or Guerande-Pkt., $5 \mathrm{c} ; 0 z ., 10 \mathrm{c} ; 1 / 4 \mathrm{lb} ., 35 \mathrm{c} ; 1 \mathrm{~b} ., \$ 1.00$. Half Long Scarlet-Pkt., $5 \mathrm{c}$; oz. $10 \mathrm{c} ; 1 / 4$ lb., $35 \mathrm{c} ; \mathrm{lb} ., \$ 1.00$.

Large White Belgian (for stock)-Oz., 5c; 1/4 lb., 15c; lb., $50 \mathrm{c} ; 5$ 1b., $45 \mathrm{c}$ per $1 \mathrm{~b}$.

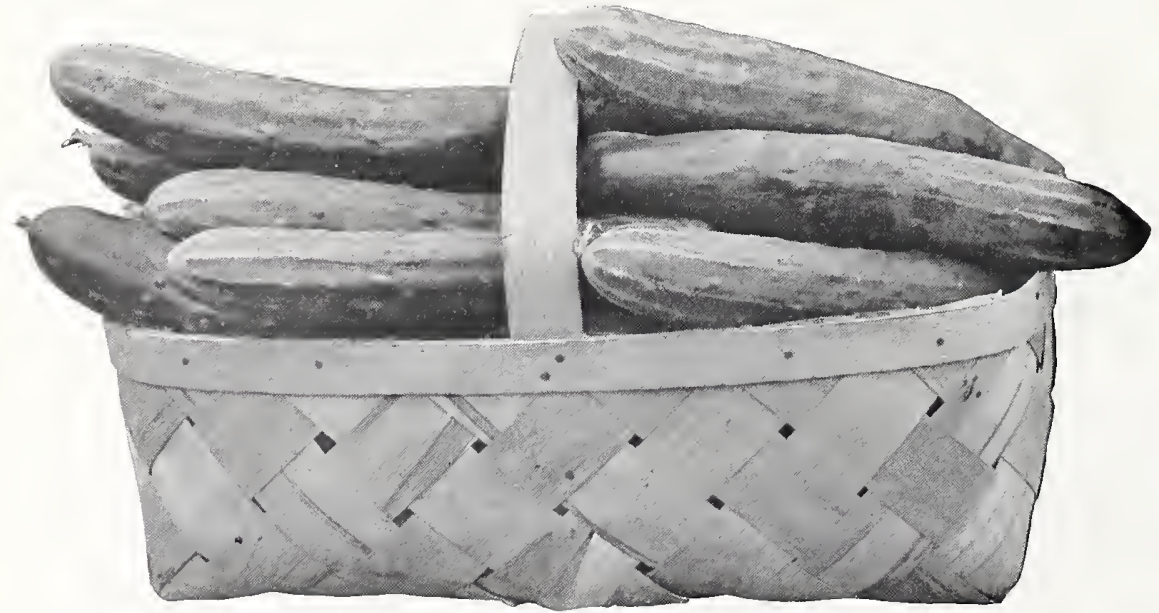

Blue Ribbon Improved White Spine Cucumber

\section{Cucumbers}

Improved Early White Spine (Blue Ribbon Strain)

Our White Spine produces a fine, smooth fruit of uniform dark green color. It is well adapted to either greenhouse or outdoor growins. Pkt. $5 \mathrm{c} ;$ oz., $10 \mathrm{c} ; 1 / 4$ lb., $30 \mathrm{c}$; 1b., $\$ 1.00$.

\section{Davis Perfect}

This variety is the selection of one of the largest growers, who has perfected a strain which is not only uniform in shape, but retains its dik green color very long, either under glass or outdoors. It contains very few seeds. Pkt., 5c; oz., 10c; 1/4 lb., $35 \mathrm{c} ; 1 \mathrm{~b} ., \$ 1.00$

Arlington White Spine-Pkt., 5c;oz., $10 \mathrm{c} ; 1 / 4$ 1b., 30c; 1b., $\$ 1.00$.

Westerfield's Chicago Pickling-Pkt., 5c; oz., 10c; $1 / 4$ lb., 25c; 1b., 75c.

Improved Lona Green-Pkt., 5c; oz., 


\section{Lettuce}

Blue Ribbon Big Boston-The finest Head Lettuce grown. This fancy strain has none of the brownish shade on the leaves that is peculiar to the ordinary variety. Pkt., 5c; oz. $20 \mathrm{c} ; 1 / 4$ lb., $60 \mathrm{c} ; 1 \mathrm{lb} ., \$ 2.00 ; 5$ lbs. at $\$ 1.75$ per $\mathrm{lb}$

Grand Rapids-Try our Blue Ribbon strain of this. Pkt., 5e: oz., 15c; 1/4 1b., 35c; lb., $\$ 1.00$

Big Boston-Regular stock. Pkt., 5e; oz., 15c; 1/4 1b., 40c; Ib., $\$ 1.25 ; 5$ Ibs. at $\$ 1.00$ per lb.

May King-Pkt., 5c; oz., 15c; 1/4 lb., 35c; 1b., $\$ 1.00$.

Imperial Cabbage-Pkt., 5e; oz., $15 \mathrm{c} ; 1 / 4$ 1b., $50 \mathrm{c} ; 1 \mathrm{~b} ., \$ 1.50$.

Black Seeded Simpson-Pkt., 5c; oz., 15c; 1/4 1b., 35c; 1b., $\$ 1$.

Improved Hanson--Plt., 5c; oz., 15c; 1/4 1b., 35c; lb., $\$ 1.00$.

\section{Kale}

Dwarf Green Curled Scotch or Norfolk-Sown in August or September. Pkt., 5c; oz., 10c; 1/1 1b., 20c; lb., 60c; 5 lbs. at $50 \mathrm{c}$ per $1 \mathrm{~b}$.

Dwarf Curled Siberian-The old standby; very hardy. Oz., $5 \mathrm{c} ; 1 / 4$ lb., $15 \mathrm{c} ; 1 \mathrm{~b} ., 40 \mathrm{c} ; 5$ lbs. at $30 \mathrm{c}$ per $1 \mathrm{~b}$.

\section{Radishes}

Extra Early White Tip Forcing-Used very largely both for market and home garden.

Extra Early Scarlet Globe-A standard Radish everywherc and immense quantities of seed are sold to market gardeners for forcing.

White Icicle-A splendid variety, producing long, white roots, crisp and of fine flavor.

Chartier Long Scarlet-Largely grown by all preferring a long Radish.

All the above at uniform price of $5 \mathrm{c}$ per pkt.; oz., 10c; 1/4 Ib., 15c; ib., 50c. Ask for prices on larger quantities.

Chinese Rose Winter-The best Fall and Winter Radishfine and crisp. Plkt., 5c; oz., $10 \mathrm{c} ; 1 / 4$ 1b., $20 \mathrm{c} ; 1 \mathrm{~b} ., 60 \mathrm{c}$.

Round Black Spanish-A fine Winter variety. Pkt., 5e; oz., $10 \mathrm{c} ; 1$. lb., $20 \mathrm{c}$; lb., $60 \mathrm{c}$.

Long Black Spanish-Same as above except as to shape. Plkt., 5c; oz., 10c; $1 / 4$ lb., 20c; 1b., 60c.

\section{Spinach}

Sow in drills, which should be about 18 inches apart, covering the seed with an inch of soil, or it can be sown broadcast. Sow in February, March and April, or in September or October, for late Fall and early Spring use. One ounce to 100 feet of drill; 20 pounds per acre, in drils, or 25 to 30 pounds broadcast. One-half pound is sufficient for an average garden.

Victoria-This remains in edible condition longer than other varietics, yet is very early. Oz., 5c;1/4 lb., 10c; $1 \mathrm{~b} ., 25 \mathrm{c} ; 10$ lbs, and over at $24 \mathrm{c}$ per $1 \mathrm{~b}$.

Round Thick Leaved-A standard variety. Forms large, thick leaves of good quality. Oz., 5c; 1/1 lb., $10 \mathrm{c} ; 1 \mathrm{~b} ., 25 \mathrm{c} ; 10$ lbs. and over at $24 \mathrm{c}$ per $1 \mathrm{~b}$.

Norfolk Savoy or Bloomsdale-A good variety for Fall seeding. Oz., $5 \mathrm{c} ; 1 / 4 \mathrm{lb}, 10 \mathrm{c} ; 1 \mathrm{~b} ., 25 \mathrm{c} ; 10 \mathrm{lbs}$. and over at $24 \mathrm{c}$ per $\mathrm{lb}$.

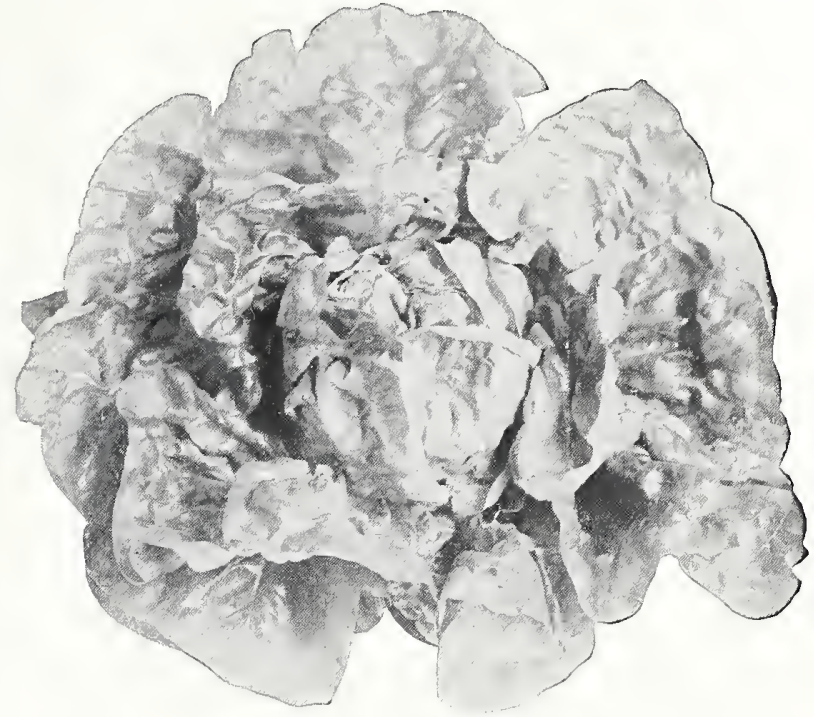

Blue Ribbon Big Boston Lettuce

\section{Turnips}

WHITE.FLESHED VARIETIES

5 lb. and over per lb, perlb.

Early Red or Purple Top (strap-leaved)......44 $40 \mathrm{c} 35 \mathrm{c}$ White Flat Dutch (strap-leaved)-White top...4 40c $35 \mathrm{c}$ W. S. \& Co.'s Improved Purple Top Globe..... 40e 350 Pomeranian White Globe-Salad or stock..... 35e $30 \mathrm{c}$ Large White Norfolk-Stock, market, salad.... 35c $30 \mathrm{c}$ Extra Early Red Top Milan-Best early......66 60 $50 \mathrm{c}$ White Egg-Rapid growing ................ 35c 30c

Long White Cowhorn-White table or stock....4 40c $35 \mathrm{c}$ Southern Prize-Stock or winter salad......... 35c $30 \mathrm{c}$ Seven Top-Grown only for winter salad.......35c $30 \mathrm{c}$

\section{YELLOW-FLESHED VARIETIES}

Purple Top Yellow Aberdeen-Stock feeding.... 35c Large Amber, or Yellow Globe-General crop... 35c W., S. \& Co.'s Imported American Purple Top Rutabaga..................... $40 \mathrm{c}$ $30 \mathrm{c}$ $30 \mathrm{c}$ $35 \mathrm{c}$

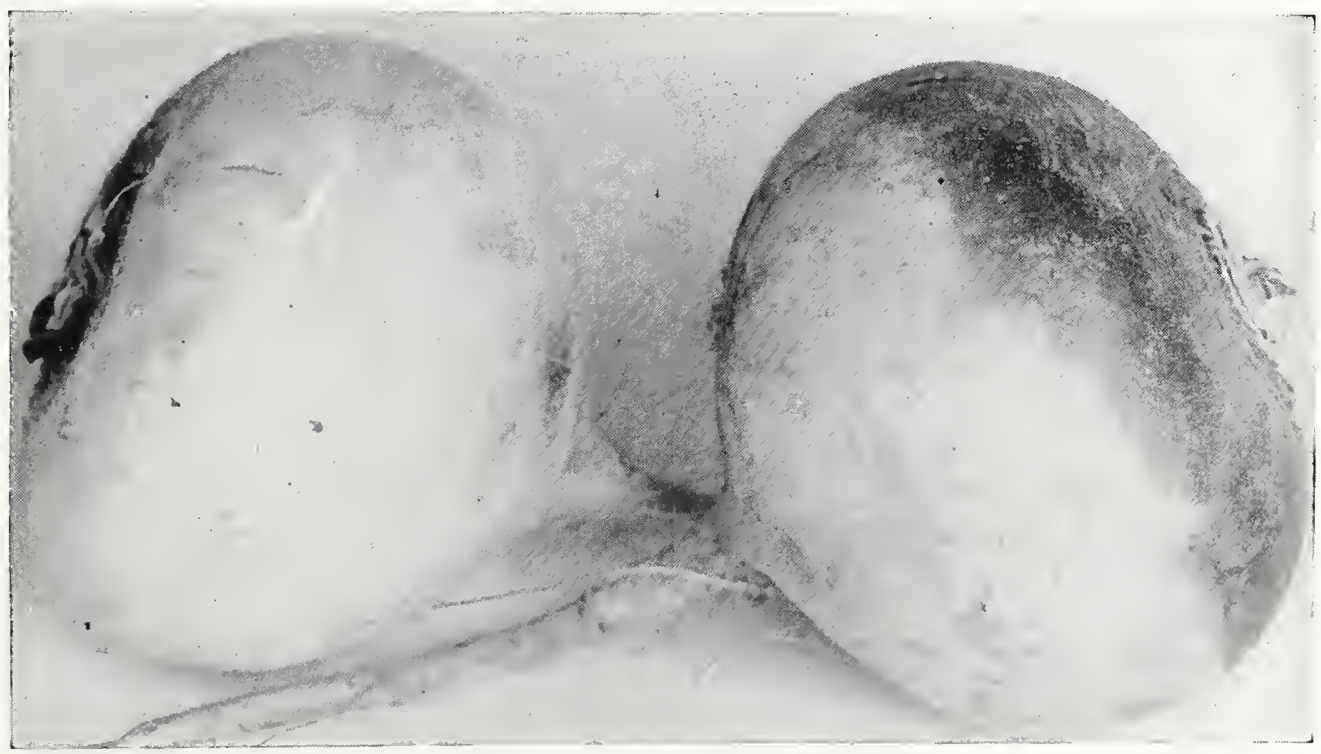

Improved Purple-top Globe Turnip-Oz., 5c; 1/4 Ib., 15c 


\section{Acme-Brand Fertilizers}

\section{Used by all the Leading Growers}

$\mathrm{T}$ HESE Fertilizers are manufactured from formulas worked out through many years of experience and observation in the field and have shown remarkable results, not only in the first crop to which they were applied, but in succeeding crops, the ingredients being or such a nature that the effect is noticeable for some time after the Fertilizer is applied.

We handle immense quantities each year and the demand is steadily growing, proving their superiority over other brands. No one will make a mistake in using "ACME BRAND."

Prices given below are net cash and F. O. B. Louisville. Special prices quoted delivered at any depot. Let us know quantity required.

\section{Wheat and Corn Fertilizer} (ACME BRAND)

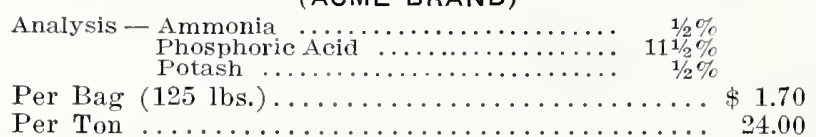

\section{Special Trucker's Fertilizer} (ACME BRAND)

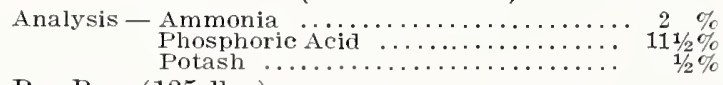

Per Bag (125 lbs.)...

Per Ton

\section{Blood, Bone and Potash Fertilizer} (ACME BRAND)

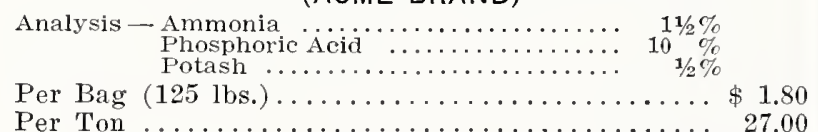

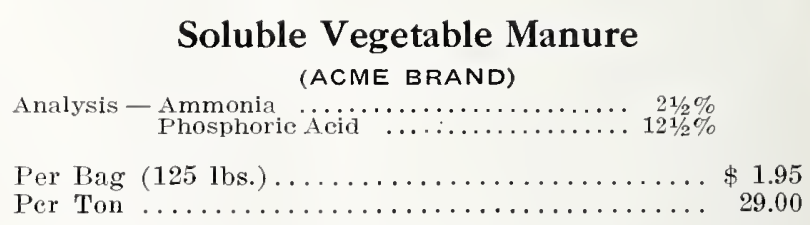

High-Grade Vegetable Fertilizer (ACME BRAND)

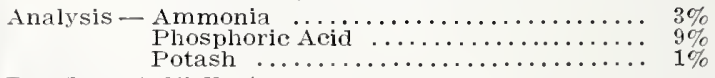

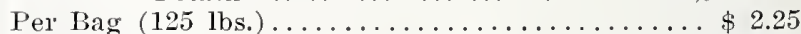

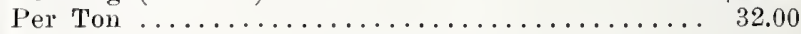

Potato and Tobacco Fertilizer (ACME BRAND)

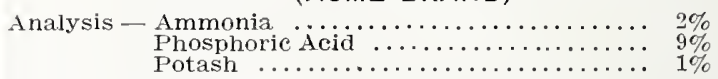

Per Bag (125 lbs.).................. \$ 2.00

Per Ton ...................... 30.00

\section{Pure Raw Bone Meal (ACME BRAND)}

Per Bag (125 lbs.) ..................... \$ 2.35

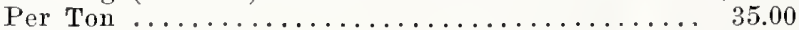

\section{Fertilizer Materials and Special Fertilizers}

\section{Acid Phosphate or Dissolved S. C. Rock}

Phosphoric acid is necessary to produce plump, heavy grains, to develop fine frnit of high flavor and to produce large highly colored flowers. In acid phosphate, we have a form readily available. Its action is quicker than either ground bone or ground phosphate rock, the other principal sources of phosphoric acid, and it is the form used in commercial Fertilizers. Can be applied at the rate of 300 to 400 pounds per acre.

$14 \%$ available - Bag (125 lbs.) ...........\$ 1.50

Ton.................... 19.00

$16 \%$ available - Bag (125 lbs.).......... 1.65

Ton ..................... 20.00

Ask for special prices on larger lots.

\section{Pulverized Sheep Manure}

A splendid article for top dressing lawns, golf courses, ete. Especially good for Fall use. Finely pulverized and absolutely free from weed seeds. Supplied in 100-pound bags only.

Price - Per 100 pounds

$\$ 1.75$

Per 1000 pounds

13.00

Per ton

25.00

\author{
Nitrate of Soda \\ (CHILIAN SALT PETRE OR NITRATE) \\ Analysis $15.65 \%$ Nitrogen
}

This comes in the form of crystals, resembling common salt. It dissolves very quickly and leaches out of the soil rapidly, so that it is of no permanent value as a Fertilizer, but is uscd largely to produce a quick growth, especially in garden crops, bringing them on very rapidly. Used largely to stimulate the growth of grass in the Spring. It can be used as a top dressing for vegetables at the rate of 100 pounds per acre after they are well started. When used in a small way, one ounce to eight quarts of water is sufficient. It is a necessary clement in the soil and in mixed Fertilizers, is usually supplied in the form of ammonia. It shows results quicktr than any other Fertilizer, as it is immediately available and is taken up by the erop at once. Booklet on the use of Nitrate free on request.

Price, 10c per lb.; 25 lbs., $\$ 1.25$; 200 lbs., $\$ 7.00$; per ton, $\$ 62.00$, F. O. B. Louisville. Prices subject to change.

Special prices quoted on large quantities. 


\section{SHAWNEE POULTRY AND PIGEON FEEDS}

\section{Prepared to meet a Purpose-Not Competition}

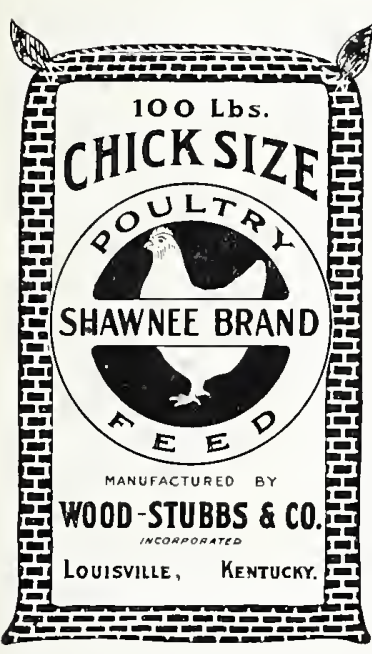

Shawnee Brand Scratch Feed

A VERY superior feed for general feeding, combining a Supplies all the elements essential to the health of the fowl, promoting good physical condition. To be fed on a litter of hay or straw two to three times a day. For heavy egg yield, feed Shawnee Laying Mash in connection with this. Combined from Corn, Kaffir Corn, Milo Maize, Red Wheat, Barley, 100 Ibs., $\$ 2.00$.

\section{Shawnee Brand Developing Feed}

B REEDERS will find this indispensable to the raising of Baroilers. Chicks thrive wonderfully on this feed, mature ordinary grain ration. Should be fed to chicks after third or fourth week. Price: 25 lbs., 75c; 50 lbs., $\$ 1.25$; 100 lbs., $\$ 2.00$.

\section{Short Cut Alfalfa}

A standard green food, invaluable for egg production. Can be fed with mashed food or used in trough by itself and is excellent scattered in brooder ${ }^{\circ}$
Price: 50 lbs., 90c; 100 lbs., $\$ 1.75$.

\section{Crushed or Granulated Bone}

An indispensable food for laying hens. Increases egg production. Two Grades - coarse and fine. Price: 5 lbs., 20c; $25 \mathrm{lbs}$., $75 \mathrm{c}$; 100 lbs., $\$ 2.50$.

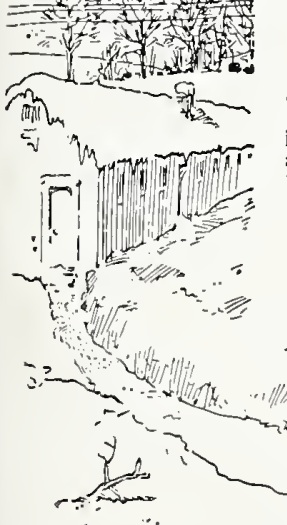

\section{Charcoal}

Our charcoal is the very best, prepared especially for poultry. No dust. A good remedy for bowel trouble, soud crop and indigestion. Promotes health in both young and old birds. Price: Ib., 10c; 5 lbs., 25c;

\section{Ground Beef Scraps}

Excellent for keeping poultry in healthy. thriving condition and aids greatly in increasing egg production. Prices: $\$ 1.00 ; 100$ Ibs., $\$ 3.25$.

\section{Shawnee Brand Laying Mash}

A SCIENTIFICALLY prepared mash to be fed wet or dry A For heavy egg yield, breeders will find this indispensable. Don't use the axe it your hen's don't lay; give them an sults are sure to follow. Get your share of winter eggs. Scientific feeding makes poultry profitable. Combined from Corn Meal, Alfalfa Meal, Bran, Middlings, Charcoal, Cotton Seed Meal, Gluten Meal and Granulated Beef Scraps, This mash should be fed in an open feed hopper and kept before the fowls at all times. Price: 25 lbs., 75 c; 50 lbs., \$1.25; 100 the fowls

Enclosed find check for Shawnee Brand Laying Mash. My hens have been laying better than ever before, and I am giving your laying mash the credit.

$$
\text { D. N. SNODGRAss, Harlan, Ky. }
$$

\section{Shawnee Brand Pigeon Feed}

A STRICTLY whole grain balanced ration. Contains a high tion of fat. A superior mixture, prepared for discriminating buy$\$ 1.25$; 100 lbs., $\$ 2.40$.

\section{Cherokee Brand Pigeon Feed}

A STRICTLY whole grain raeconomy and results. Prepared after the same formula as our Shawnee Brand, but containing smaller percentage of Canada smaller percentage of Canada Peas. A strictly first-class mixupon to produce fat squabs. Price: 25 lbs., $65 \mathrm{c}$; 50 Ibs., $\$ 1.15$; 100 lbs., $\$ 2.20$.

Baton Rouge, La.-We wish to advise that the writer has been raising pigeons for several years and we find your Shawnee Brand Pigeon Feed is the best we have ever been able to obtain, and you are at liberty to use our name in for past favors and trusting that we may be able to give you the cream of the Louisiana business, we are,

BATON ROUGE HOMING LOFTS.

\section{Wild Seed Mixture}

Nature's food for birds. A remarkable food for chickens baby chicks, guineas, turkeys, pigeons, etc. These seeds will give your birds increased vigor. prevents diarrhea and will reduce mortality in young chicks over 50 per cent Price: 25 Ibs., 50c; 50 lbs., $\$ 1.00$; 100 lbs., $\$ 1.50$.

Crushed Oyster Shell

Every raiser of poultry, whether small or large, should keep an adequate supply of shell on hand at all times. This contains the elements necessary to the formation of the egg shell. In two sizes, coarse and fine. Price: $5 \mathrm{lbs}, 10 \mathrm{c} ; 100 \mathrm{lbs}$., $70 \mathrm{c}$.

\section{Mica Crystal Grit}

One of the most valuable grits introduced. With the aid of this grit the hen can properly grind and masticate her food. This grit, apart from being hard and sharp, acts as a tonic This grit, a part from being hard and sharp, acts as a tonic of the bird. Price: 5 lbs. $10 \mathrm{c}$; 100 lbs., $70 \mathrm{c}$.

\section{Crysco Grit}

This is a shell producer and grit in one. Contains 90 per cent pure carbonate or lime. Makes hard egr shells and increases the hen's laying power. Price: 5 lbs., 10c; $100 \mathrm{lbs}, 70 \mathrm{c}$ 


\section{Spring Flowering Bulbs}

Bulbs arrive from Holland about September 15 th. All orders received before this will be held and shipment made in order received, soon as the stock reaches us.

\section{Snowdrop (Galanthus)}

The first of all spring flowers, frecuently blooming while there is snow on the ground in Fcbruary. Small drooping white flowers. 15c per dozen; 25 for $30 \mathrm{c} ; 100$ for $\$ 1.00$, postpaid.

\section{Crocus}

A flower which everyone linows. We have four colors in namcd varieties, separate colors, Yellow, White, Purple and Striped, or will send
these mixed as desired. 20c per dozen; 25 for 25c, postpaid; $90 \mathrm{c}$ per 100 , or 250 for $\$ 2.00$ by exoress.

\section{Tulips}

TUIIPS are the most popular of all spring flowers and considering 1 their beauty for garden decoration, as well as their value as cut-. flowers, we should grow many more of them than we do. They can be planted from scptember to Deeember, though the earlier the better. The late-planted bulbs bloom later in the Spring. Set them four to six inches apart and four inches deep. If planted in beds, elevate the latter a little in the center to prevent water standing on them. Don't apply any mulch until the ground is well frozen, otherwise your bulbs will be growing ahead of time and you will have trouble. They will come up through the mulch and be weak and spindling. Any covering placed over them should be removed as soon as growth begins in the spring. If you set them deep enough so that the frost won't lift them out you don't need to cover any hardy bulbs but lilies. Don't use stable manure in the ground unless it is very well rotted. Bone meal is best. Scatter it so it just covers the ground, then spade it in. Lift the bulbs just as the foliage is turning yellow; heel in in a shady place for a week, then clean off and lay away in a cool, dry place untll Fall.

\section{Single Early Tulips}

Belle Alliance-(12) - A large, scarlet flower of fine form and substance; a splendid bedder. $5 \mathrm{c}$ each; $30 \mathrm{c}$ per dozen, postpaid; 25 for $50 \mathrm{c}$;
$\$ 1.50$ per 100 .

Cottage Maid-(12)-A bright pink, very largely used for forcing and bedding; a good tulip of its colors. $5 \mathrm{c}$ each; 30 per dozen, postpaid: 25 for $50 \mathrm{c}$; $\$ 1.50$ per 100 .

Chrysolora-(15)-An extra fine golden yellow; fine for all purposes. $5 c$ each; 30c per dozen, postpaid; 25 for $50 \mathrm{c} ; \$ 1.50$ per 100

Crimson Brilliant-(15)-Brilliant scarlet; an extra fine bcdder. 5c each; 20c per dozen, postpaid; 25 for $30 \mathrm{c} ; \$ 1.00$ per 100.

Coeleur Cardinal-(13)-A large and very handsome flower; brilliant crimson with purple sheen on the outer side of the petals, $5 \mathrm{c}$ each: $50 \mathrm{c}$ per dozen, postpaid; 25 for $75 \mathrm{c} ; \$ 2.50$ per 100 .

Keizerskroon-(16)-This old-time variety is planted by the thousand. Very early, very large, and one of the handsomest of all. A bright red with broad margin of yellow. $5 \mathrm{c}$ each; $50 \mathrm{c}$ per dozen, postpaid; 25 for $75 \mathrm{c} ; \$ 2.25$ per 100 .

La Reine (-10)-White, slightly tinged with rose; good bedder and largely used for forcing. 5c each; 20c per dozen, postpaid; 25 for $30 \mathrm{c}$; $\$ 1.00$ per 100

Rose Gris de Lin-(10)-A good light pink variety of upright growth and a little later than most others. $5 \mathrm{c}$ each; 20c per dozen, postpaid; 25 for $30 \mathrm{c} ; \$ 1.00$ per 100 .

\section{Double Early Tulips}

Alba Maxima - (11) - A medium early, very large double white: fine bedder. $5 \mathrm{c}$ each; $30 \mathrm{pcr}$ dozen, postpaid; 25 for $40 \mathrm{c} ; \$ 1.25$ per 100

Gloria Solis-(10)-Red, bordered with gold; somewhat like a double Keizerskroon. $5 \mathrm{c}$ each; $30 \mathrm{c}$ per dozen, postpaid: 25 for $40 \mathrm{c} ; \$ 1.25$ per 100 .

Lord Beaconsfield-(10)-One of the largest pink tulips; deep rose color and very double $5 c$ each 40 c per dozen, postdeep rose color and very double.
paid; 25 for $50 \mathrm{c} ; \$ 1.50$ per 100 .

Murillo-(11)-Very double, light rose pink; very largely used both for bedding and forcing. 5c each; 30 per dozen, postpaid; 25 for $40 \mathrm{c}$; $\$ 1.25$ per 100 .

Rubra Maxima-(10)-Deep red; a very geed bedder. $5 \mathrm{c}$ each; 35e per dozen, postpaid; 25 for $45 \mathrm{c} ; \$ 1.50$ per 100 .

\section{Double Early Tulips Mixed}

The fanciest stock we can buy. Large bulbs and good assortment of colors. 2 for $5 \mathrm{c} ; 25 \mathrm{c}$ per dozen; 25 for $35 \mathrm{c} ; \$ 1.25$ per 100, all postpaid.

\section{Cottage Garden or May Flowering Tulips}

Bouton d'Or-(18)-An old variety, but still one of the lead; a beautiful golden yellow of formal growth and grand 25 for $40 \mathrm{c} ; \$ 1.50$ per 100 .

Fulgens-(20)-A dark scarlet with long reflexing petals. Very large flowers on long stems. A great beauty and worthy of very general planting. 5c each; $40 \mathrm{c}$ per dozen, postpaid; 25 for $60 \mathrm{c} ; \$ 2.00$ per 100 .

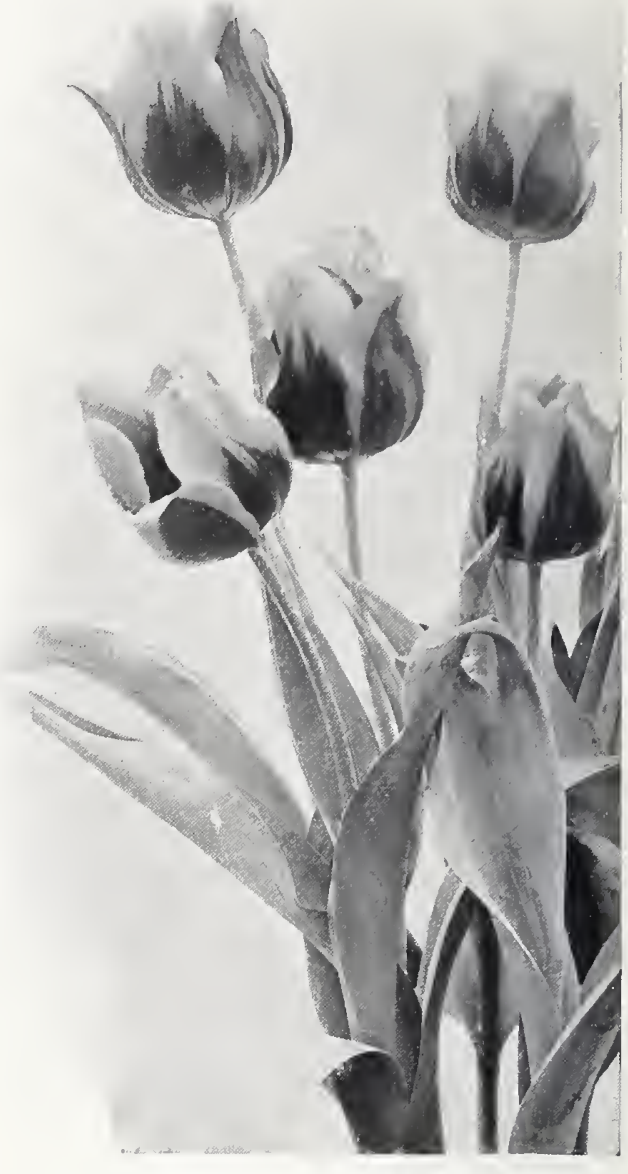

Early Tulip Keizerskroon

\section{Single Early Tulips Mixed}

These are the best grade of Mixed Tulips sent to this country. An extra fine assortment. 2 for 5 c; 25 c per dozen; 25 for $35 c$; $\$ 1.25$ perr 100 , all postpaid.

Picotee (Maiden Blush)-(18)-White, margined with deep rose which suffuses the whole flower as it ages. Widely reflexing petals. Very popular and planted everywhere. $5 \mathrm{c}$ cach; 25e per dozen, postpaid; 25 for $40 \mathrm{c}: \$ 1.50$ per 100 .

\section{Cottage Garden Tulips in Mixture}

A fancy mixture of many colors and varieties. 5c each; $30 \mathrm{c}$ per dozen, postpaid; 25 for $50 \mathrm{c} ; \$ 1.50$ per 100

\section{Darwin Tulips}

Baron de la Tonnaye-(26)-Deep rose with light rose edge. Very tall and stately. Grand for bedding or shrubbery planting, and one of the most lasting of all. $5 \mathrm{c}$ each; $40 \mathrm{c}$ per dozen, postpaid. 25 for 60e; $\$ 1.75$ per 100 .

Clara Butt-(20)-Clear pink, flushed with salmon rose. A very pretty flower and extra fine for bedding. $5 \mathrm{c}$ each; $25 \mathrm{c}$ per dozen, postpaid; 25 for $40 \mathrm{c} ; \$ 1.50$ per 100 .

Gretchen (Margaret)-(20)-Delicate flesh color, medium sized flowers; beautiful as a cut flower. $5 \mathrm{c}$ each; $25 \mathrm{c}$ per dozen, postpaid; 25 for $40 \mathrm{c}$; $\$ 1.25$ per 100.

Harry Veitch - (26) - Brilliant blood red on long stems. Grand for bedding. $5 \mathrm{c}$ each; $40 \mathrm{c}$ per dozen, postpaid; 25 for $60 \mathrm{c} ; \$ 1.75$ per 100

\section{Mixed Darwin Tulips}

This mixture will give one an idea of the many beautiful colors there arc in Darwins. We are importing the fanciest mixture obtainable. 5c each; 40c per dozen, postpaid; 25 for $60 \mathrm{c}: \$ 1.75$ per 100 .

If interested in Bulbs, ask for Special 16-page Catalog. Sent Free. 


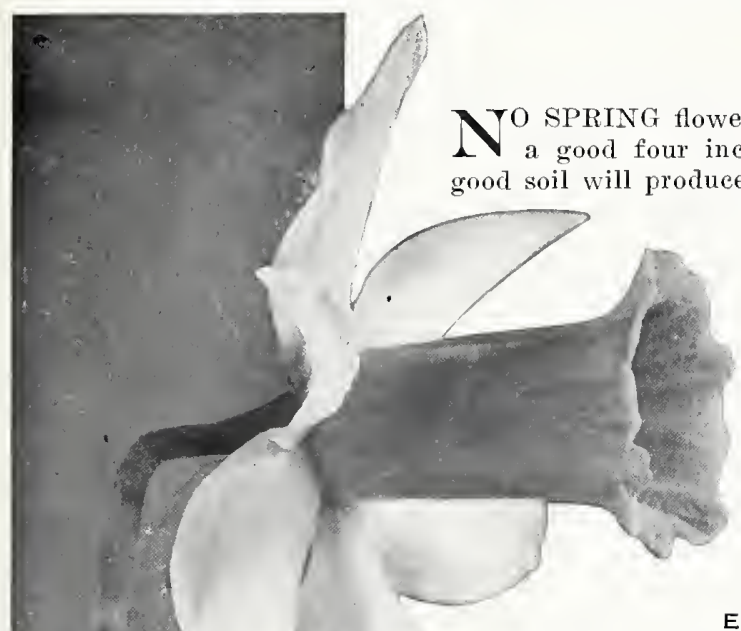

\section{NARGISSUS}

TO SPRING flowering bulb gives greater returns than the Nareissus. Plant them good flowers. Do not take them up until the seeond year after onee if possible. They ean be dried off and held till Fall, but do better if planted baek right away. For this reason, too, you should order Narcissus bulbs as early as possible in the Fall September the 15 th to October 15 th being the time to proeure them, and plant at onee. Never put fresh manure in the soil; use bone meal or some eommercial fertilizer lightly scattered over the soil and dig it in, or if you have well deeayed manure, you ean use a moderate amount, barely covering the ground. Plant deep enough and you won't have to eover or muleh in the Fall.

\section{Large Trumpet Narcissus}

Emperor-Large golden yellow trumpet, deep primrose perianth. Planted more largely than any other variety. Extra fine. 5e each; 400 per dozen, postpaid; 25 for $60 \mathrm{c} ; \$ 2.00$ per 100 .

Mrs. Thompson-A pure white flower with beautifully frilled trumpet. Very free flowering and early. 5c each; $25 \mathrm{c}$ per dozen, postpaid; $25 \mathrm{for}$ $50 \mathrm{c} ; \$ 1.50$ per 100 .

Princeps-An old-time variety; primrose perianth and yellow trumpet. 2 for $5 \mathrm{c}$; $30 \mathrm{c}$ per dozen, postpaid; 25 for $40 \mathrm{c} ; \$ 1.25$ per 100 .

Victoria-This is the standard bicolor trumpet daffodil. It holds the same place in its color as the Emperor. Very free flowering and hardy. 2 for $15 \mathrm{c} ; 50 \mathrm{c}$ per dozen, postpaid; $\$ 2.60$ per 100.

\section{Short Trumpet Narcissi}

Barri Conspicuus-Iarge soft yellow perianth, short cup, edged with orange-scarlet. An extra good variety: fine for naturalizing. 3 for $10 \mathrm{c} ; 25 \mathrm{c}$ per dozen, postpaid; 25 for $40 \mathrm{c} ; \$ 1.25$ per 100

Elvira-A splendid variety, having two and three flowers to a stem-large, pure white blooms with vellow eve. and of great substance. 2 for $15 \mathrm{c} ; 40 \mathrm{c}$ per dozen, postpaid; 25 for $60 \mathrm{c} ; \$ 2.25$ per 100 .

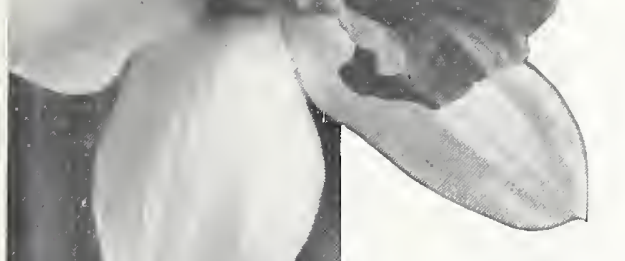

Sir Watkin - A very large flower and popular on account of its vignr and fine blooming qualities. Perianth, sulphur yellow; cup, yellow, tinged with orange. $40 \mathrm{c}$ per dozen, postpaid; 25 for $60 \mathrm{c} ; \$ 2.00$ per 100

Mrs. Langtry-Very generally planted and fine for cutting and naturalizing. Pure white perianth and large white cup, edged with yellow. 2 for $5 \mathrm{c} ; 25 \mathrm{c}$ per dozen, postpaid; 25 for $30 \mathrm{c} ; \$ 1.00$ per 100.

Poeticus Ornatus-A splendid variety, very largely grown. Early and free flowering: white perianth, with yellow cup edged with scarlet. 2 for $5 \mathrm{c} ; 25 \mathrm{c}$ per dozen, postpaid; 25 for $35 \mathrm{c}$; $\$ 1.25$ per 100 .

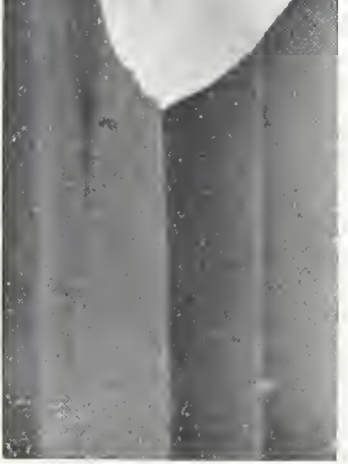

Recurvis (Common Poeticus)-Pure white perianth, with scarlet cup. Very hardy. Late 2 for $5 \mathrm{c}$; $20 \mathrm{c}$ per dozen, postpaid; 25 for $30 \mathrm{c} ; \$ 1.00$ per 100 .

\section{Jonquils}

The Trumpet Daffodil is very generally known as the Jonquil, but the true Jonquil is of entirely different form. It flowers very early and is fragrant. It usually has three flowers to a stem, each bulb producing several stems.

Campernella Rugulosus-The largest flowered Jonquil. Fine for naturalizing. Beautiful golden yellow. 2 for $5 \mathrm{c} ; 20 \mathrm{c}$ per dozen, postpaid; 25 for $35 \mathrm{c} ; \$ .125$ per 100

\section{Double Daffodils}

Von Zion (Easter Flower) - pure golden yellow, very double, fancy double nose bulbs. 2 for $15 \mathrm{c} ; 50 \mathrm{c}$ per dozen, postpaid; 25 for $75 \mathrm{c} ; \$ 2.50$ per 100 .

\section{Fancy Mixed Narcissi and Daffodils}

Narcissus Emperor

\section{Paper White or Polyanthus Narcissus}

\section{Grows in a bowl of water and will flower in four to six weeks. Try it.}

This is the bunch-flowered pure white variety grown so largely by florists during the winter and by amateurs in bowls of ravel and water. They may be flowered in about six weeks. Procure a glass bowl of any receptacle which will hold the

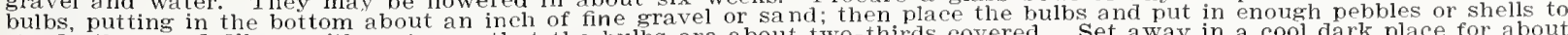

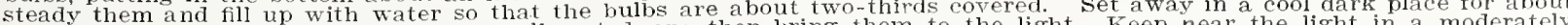
two weeks or until the bulbs are very well rooted, anu then bring them to the light. Keep near the light in a moderately warm room. If over 70 degrees the foliage will grow up very rank and the flower stems will blight.

We are only handling one size of bulb this year - the largest sent out. Extra fine. 3 for $15 \mathrm{c}$; $40 \mathrm{c}$ per dozen; 25 for $60 \mathrm{c}$ : $\$ 2.00$ per 100 , delivered anywhere.

Grand Soliel d'Or-A beautiful golden yellow variety of the above. 2 for $15 \mathrm{c}$; $50 \mathrm{c}$ per dozen, postpald; 25 for $75 \mathrm{c}$; $\$ 2.50$ per 100. 


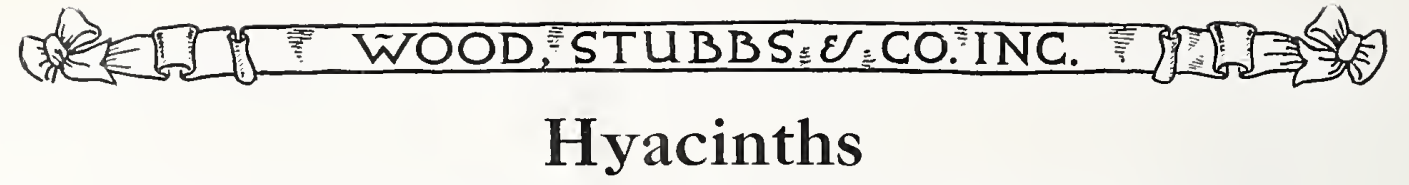

Prices by the dozen are postpaid, all others by express at purchaser's expense

$\mathrm{T}$

IHE HYACINTH can be grown in pots or in water, for the latter purpose using a regular Hyacinth glass. When planted in pots, place one bulb in a four-inch pot or three or four in a bub pan, using any good garden soil and placing drainage of some sort in the bottom of the pot. The bulbs should be planted even with the surface, the pots watered thoroughly and placd in a cool, dark place for six or eight weeks, watching that the ground does not get dry at any time. They can also be set outdoors in tne garden, the pots being sunk even with the surface in a well drained place, and if the pots are stood on a bed of ashes so much the better, then covered with several inches of soil and finally mulched to keep out frost. They will keep moist this way if well watered when put in, and can be brought into the house as needed for succession of bloom. Keep in a rather cool room. If very warm the flower stalk will blast or not come up above the ground. Do not let them dry out at any time. When planted in the garden, set six inches apart and five inches deep. Take up when the foliage is turning yellow and reset in the Fall. Hyacinths like a sandy soil and will thrive better in it than in any other. Do not use fresh manure about them or in the soil. Bone meal as advised for Tulips is best.

\section{Single Named Hyacinths Extra Fancy Bulbs}

Admiral Courbet-One of the new ones. A deep víolet blue, producing an immense spíke. $10 \mathrm{c}$ each $\$ 1.00$ per dozen; 25 for $\$ 1.50 ; \$ 5.50$ per 100 .

General DeWet-Light pink, very similar to Grand Maitre in form and size, being a sport of thís grand
variety. 10c each; $\$ 1.00$ per dozen; 25 for $\$ 1.50$; variety. $10 \mathrm{c}$
$\$ 5.50$ per 100 .

Grand Maitre-Deep lavender. In great demand on account of its beautíful color and splendid spikes. $10 \mathrm{c}$ each; $\$ 1.00$ per dozen; $\$ 5.50$ per 100 .

Jacques-An immense rose pink of perfect pyramíd shape. Grand. $10 \mathrm{c}$ each; $\$ 1.00$ per dozen, $\$ 5.50$ per 100 .

King of the Yellows-Considered the finest Yellow Hyacinth, being a real yellow color. $10 \mathrm{c}$ each; $\$ 1.00$ per dozen; $\$ 5.50$ per 100 .

La Grandesse - The very 1inest of all the white Hyacinths; large spike and beautiful bell. $10 \mathrm{c}$ each; $\$ 1.00$ per dozen; $\$ 5.50$ per 100

La Victoire-The finest red Hyacinth in existence; forms a long, heavy and beautíful shaped spíke: brilliant red in the garden, but of lighter shade if grown in the house. $10 \mathrm{c}$ each; $\$ 1.00$ per dozen; $\$ 5.50$ per 100

Lady Derby-Bright rose pink; produces a perfect spike on strong stem and is a beautíful color $10 \mathrm{c}$ each; $90 \mathrm{c}$ per dozen; $\$ 5.00$ per 100 .

Maríe-Dark purple. A very fine early variety. $10 \mathrm{c}$ each; $\$ 1.00$ ner dozen; $\$ 5.00$ per 100 .

Mansfield-Ruby víolet: very fine spikes. A good dark variety. $10 \mathrm{c}$ each; $90 \mathrm{c}$ per dozen; $\$ 5.00$ per 100 .

Menelik-Very dark purplish blue. Probably the darkest of all hyacintlis and the best of its color $10 \mathrm{c}$ each; $90 \mathrm{c}$ per dozen; $\$ 5.00$ per 100

Ornament Rose-Soft flesh pink. A most beautiful color and an extra fine spike and flower. 10c each; $\$ 1.00$ per dozen; $\$ 5.50$ per 100 .

Perle Brilliant-Líght blue; produces a large erect spike of most perfect shape, the bells being sky blue, shading líghter in the cneter. Beautiful. 10c each: $\$ 1,00$ per dozen; $\$ 5.50$ per 100

Roí des Belges-(King of the Belgíans)-A very popular red, of fine form; produces a fine, erect. closely-filled spike. 10c each; 90c per dozen; $\$ 5.00$ per 100.

Schoetel-Forms a long, perfect spíke of clear porcelain blue color. Very fine. $10 \mathrm{c}$ each; $90 \mathrm{c}$ per dozen: $\$ 5,00$ per 100 .

\section{SPECIAL OFFER}

One each of these fancy named Hyacinths, 15 in all, for $\$ 1.00$, postpaid.

\section{Fancy Unnamed Hyacinths}

\section{Separate Colors-Large Bulbs-16-18 Centímeter Síze}

White, Blush Whíte, Light Blue, Dark Blue, Light Pink, Dark Pink, Red, Yellow and Mixed of the above. 5c each; 50c per dozen; $\$ 3.00$ per 100

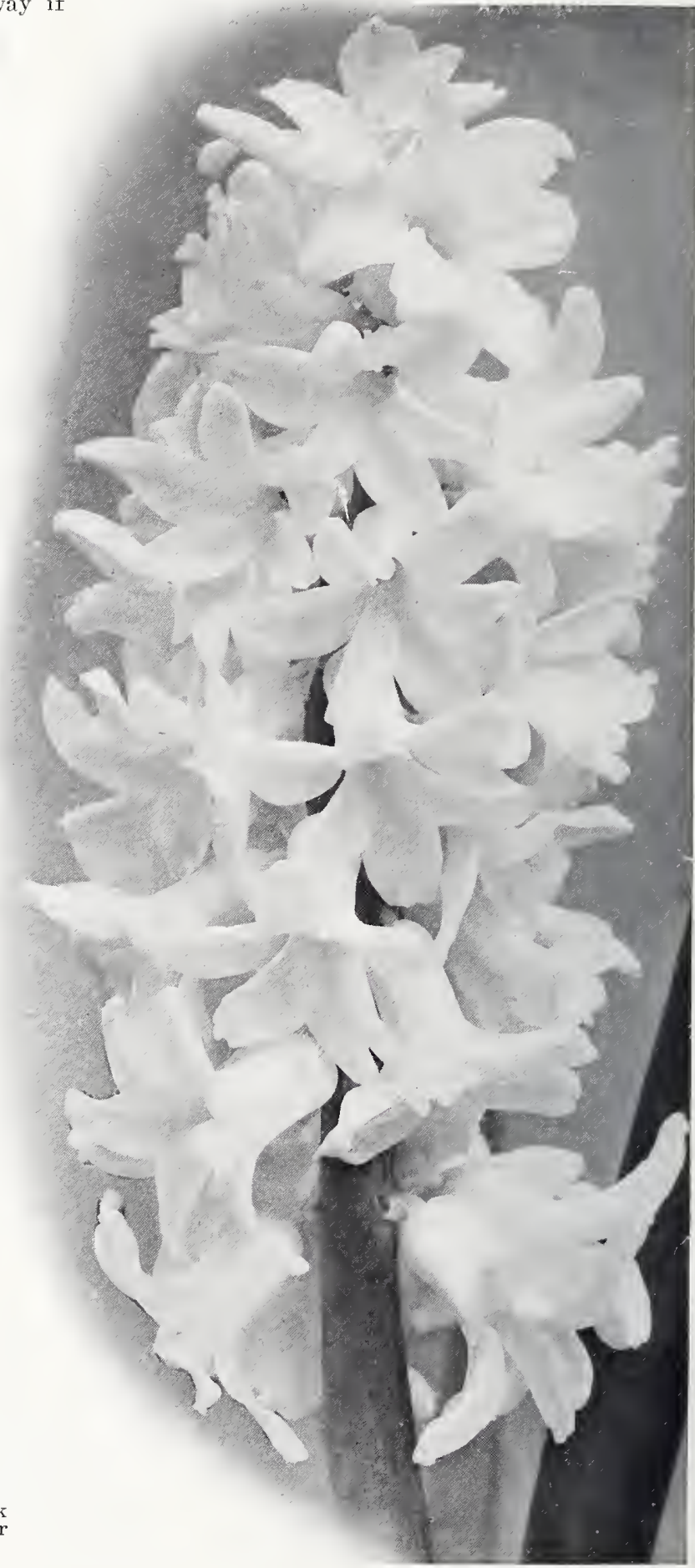




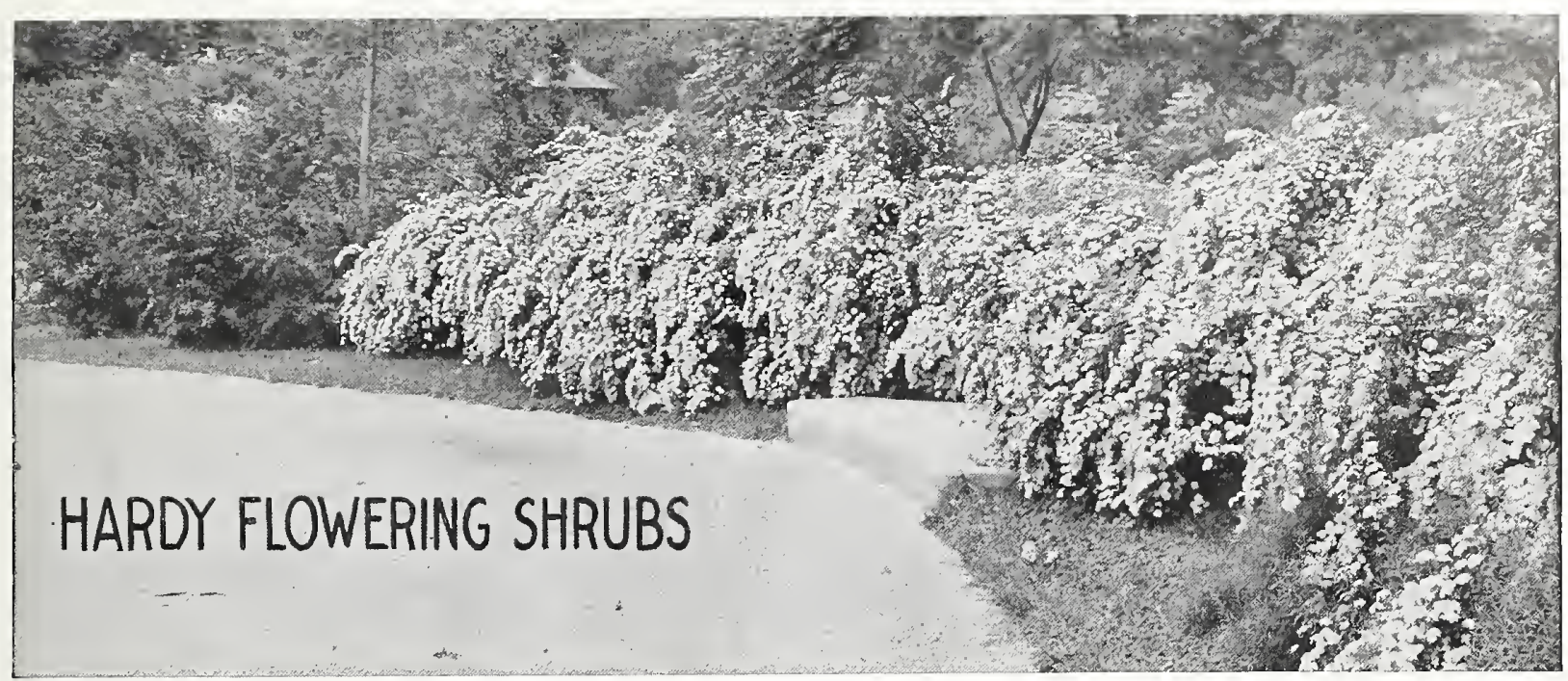

We have several acres of ornamental shrubs and send out fine bushy stock. All quoted on this page are 2 to 3 feet size, and are sent by express at purchaser's expense.

\section{Buddleia Veitchiana}

Sometimes called Summer Lilac. A late flowering shrub. blooming from July on to Fall. Grows about four feet tall and produces long sprays of violet mauve flowers; usually dies to the ground each Winter, but makes such strong each year; very fine. Price, $25 \mathrm{c}$ each; $\$ 2.50$ per doz., prepaid.

\section{Berberis (Barberry)}

Berberis Thunbergii, or Japanese Barberry, is more largely used than any other shrub, being absolutely hardy everywhere, growing in sun or shade and especially valuable as a border for taller growing shrubs. Also used as a low growing hedge plant and for outlining walls or drives; foliage is very pretty and remains green until late Fall. The flowers are in significant, but red berries are produced which hang on the
bush in Winter. 18 inch, bushy, $15 \mathrm{c}$ each: $\$ 1.50$ per dozen; 24 inch, bushy, 20c each; $\$ 2.00$ per dozen.

\section{Calycanthus}

Carolina Allspice-An old-time shrub, producing in early Summer dark chocolate colored flowers of delightful fragrance. The bushes become quite large and are of upright growth. 2 to 3 feet, $30 \mathrm{c}$ each; $\$ 3.00$ per dozen.

\section{Cydonia (Japan Quince)}

A bushy shrub, growing several feet high and producing close to the branches, beautiful deep red blossoms before the leaves appear. 3 to 4 feet, 30 c each.

\section{Forsythia}

A noticeable shrub, as it blooms very early, producing bright yellow flowers all along the branches before the leaves appear. Very hardy.

Intermedia - The hardiest and best variety of upright growth. 2 to 3 feet, $30 \mathrm{c}$ each.

\section{California Privet}

A shrub that is used very largely for hedges, being the most satisfactory variety for this purpose. Should be rlanted in double rows, foot apart. Set "hit and miss" to form a thick growth at the base. Should be cut off to four inches above the ground when first planted. After the first year's growth can be pruned in June. 18 to 24 inches, per $100, \$ 3.00 ; 2$ to 3 feet, $\$ 4.00$ per $100 ; 3$ to 4 feet, $\$ 5.00$ per 100 .

\section{Hydrangea}

This is one of the most popular of all shrubs, the large heads of bloom being very attractive and the plants always give a good account of themselves. Require plenty of water to do their best.

H. Arborescens Grandiflora-A shrub which blooms after all the Spring flowering varieties are over. It becomes very bushy and will stand cutting back right to the ground each year, the flower heads being produced on the new wood. The year, the flower heads being produced on the new wood. The this one of our most valuable shrubs, 18 to 24 inches, $30 \mathrm{c}$ each; $\$ 3.25$ per dozen.

H. Paniculata Grandiflora-A grand shrub, flowering in late Summer and producing immense heads of bloom. Like the above this will stand severe pruning and larger flowers are produced when branches are cut back. 2 to 3 feet, $30 \mathrm{c}$ each; $\$ 3.00$ per dozen.

\section{Philadelphus (Mock Orange)}

Very well known as Syringa or Mock Orange on account of the flowers resembling orange blossoms. They will grow well in the shade, although doing best in full sunlight.

P. Coronaria-The old-fashioned type with very fragrant creamy-white flowers; early; grows six to eight feet tall. 2 to $3 \mathrm{feet}, 30 \mathrm{c}$ each; $\$ 3.00$ per dozen

P. Grandiflora-Has much larger flowers than Coronaria, but has scarcely any fragrance is also much later than the or dinary type. 2 to 3 feet, 30 c each; $\$ 3.00$ per dozen.

\section{Spiraea Van Houttei}

(See illustration at top of page.) Used more largely than any other shrub. Absolutely hardy everywhere and never fails to flower. The entire shrub is covered in early summe with long sprays of white bloom. The natural growth of the shrub is very graceful and it reauires little pruning, but if this is found necessary, do it immediately after t
flowered. 2 to 3 feet, $30 \mathrm{c}$ each; $\$ 3.00$ per dozen.

\section{Snowball}

Opulus Sterlis (Common Snowball)-A great favorite and very hardy; flowers freely, regardless of the size of the bush 2 to 3 feet, $30 \mathrm{c}$ each.

\section{Special Offer No. 18}

One each of the following: Spiraea Van Houttei, Hydrangea Pan. Grand., Cydonia, Philadelphus Coronaria, dia, Forsythia, Snowball-seven fine regular stock, for $\$ 1.50$ by express at purchaser's expense. 


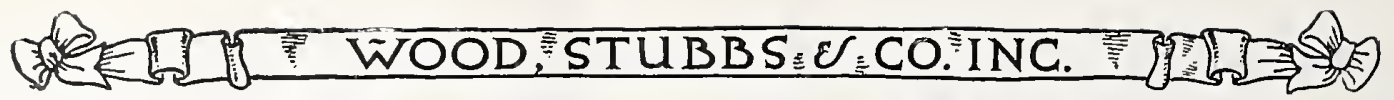

\title{
Bleeding Heart
}

Big home-grown clumps of this old favorite. Should be planted in September.

$35 \mathrm{c}$ each, postpaid 3 for $90 \mathrm{c}$

\section{Peonies}

\section{Three for One Dollar, Postpaid}

When you buy Peonies from us you get the finest large flowering varieties-not the common, unnamed type. Try the following and see how beautiful the better varieties are:

One Festiva Maxima, White; One Edulus Superba, Pink; One Delachii, Deep Red.

\section{Special Offer No. 15}

\section{Darwin Tulips}

We sold ten times as many of these last year as in any previous season. This year we have 27 varieties, the very cream of the whole list. They are the finest Tulips in existence. We will send one bulb of each of the 27 varieties for $75 \mathrm{c}$, postpaid, all correctly labeled. Ask for our Bulb List and read the descriptions of these wonderful flowers. They would cost $\$ 1.80$ if ordered separately.

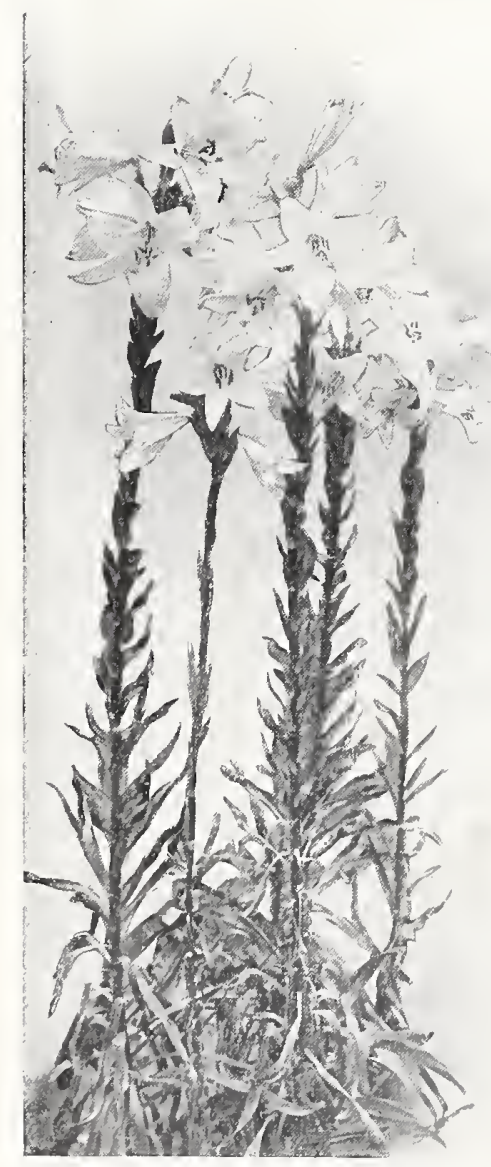

Candidum or Madonna Liiy

\begin{abstract}
(20y) wast
Special Offer No. 20

May Flowering Tulips

Three each of eight varieties, 24 in all, for $40 \mathrm{c}$, postpaid.

We urge you to try these Tulips. They always give a good account of themselves and flower after all early Spring bulbs are over. This special offer will enable you to get an idea of are over, This special offer will enable you to get an ldea of their beauty. Three Bouton dOr, 3 Fulgens, 3 Gesneriana Spathulata, 3 Picotee, 3 La Merveille, 3 The Fawn, 3 Gesneri-
ana Lutea, 3 Fairv Queen. Full deseription in our Bulb List. Ask for copy.

\section{Freesia}

A fine little plant for pot culture. Place six or eight bulbs. in a five-inch pot, Do not put in the dark, as instrulbs, 4 for $10 \mathrm{c}$; per dozen, $20 \mathrm{c}$; $\$ 1.25$ per 100 , postpaid.

\section{Candidum or Madonna Lillies}

We have several thousand of these growing in our nursery, all in bloom at the present writing (June 10th) and having four to ten flowers to the bulb. These will be ripe by August 1st and should be planted early as possible. 20e each; 2 for $35 \mathrm{c}$; $\$ 3.00$ per doz, postpaid; $\$ 8.00$ $\$ 3.00$ per doz, posted bulbs. per 100 for selected largest Jumbo Bulbs - The largest bulbs reaching this country. Ready about August 20th to September 15th. 25c each; $\$ 10.00$ per 100 by express

\section{Try This}

\section{Colchicum or Autumn Crocus}

Autumnale Major - Produces a big bottom and can be placed in a saucer, bowl or any shallow receptacle, where it will bloom profusely with uot either water or soil producing large light purnle blooms. When through flowering the bulbs can be planted in the ground like other crocus and, being perfectly hardy will orow and flower the following season about September. followin or immediate bulbs they can be planted in the open ground, three inches deep and four inches apart. and will flower there very shortly after planting. Ready about August 20 10c each; 75c per dozen, postpaid; $\$ 4,00$ per 100 by express.

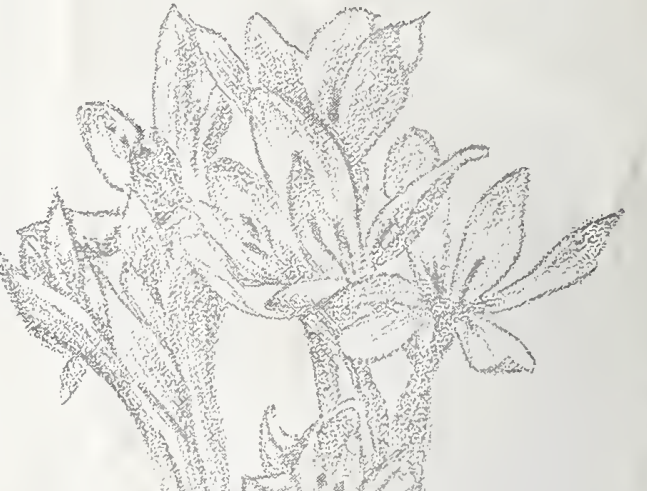

